\title{
31. DATA REPORT: METAMORPHIC MINERALOGY OF LEG 153 GABBROS ${ }^{1}$
}

\author{
Laura Gaggero ${ }^{2}$ and Luciano Cortesogno ${ }^{2}$
}

\begin{abstract}
The $117.38 \mathrm{~m}$ of gabbroic core drilled during the Ocean Drilling Program (ODP) Leg 153 at Sites 921-924 in the MidAtlantic Ridge between $23^{\circ} \mathrm{N}$ and the Kane Fracture Zone exhibits a remarkable primary compositional heterogeneity, such as magmatic layering, intrusive contacts, and late magmatic veining, which expresses a succession of magmatic events. Magmatic features include random shape fabric and magmatic layering; the successive deformative overprint occurred in metamorphic conditions. The ductile deformation, generally concentrated in the discrete domain of the gabbro, is associated with the metamorphic assemblages (1) olivine + clinopyroxene + orthopyroxene + plagioclase + ilmenite + Ti-magnetite, (2) olivine + clinopyroxene + plagioclase + ilmenite + Ti-magnetite + red hornblende. At lower temperatures, brittle deformation prevails, and the following assemblages develop: (3) clinopyroxene + plagioclase + red-brown hornblende + Ti-magnetite + magnetite(?) + ilmenite, (4) plagioclase + brown hornblende + Ti-magnetite + magnetite + hematite + titanite \pm Ti-oxide, (5) plagioclase + green hornblende + magnetite + titanite, (6) plagioclase + actinolite + chlorite + titanite + magnetite, (7) albite + actinolite + chlorite + prehnite \pm epidote \pm titanite, and $(8)$ albite + prehnite + chlorite \pm smectite
\end{abstract}

\section{INTRODUCTION}

The purpose of this paper is to characterize the metamorphic mineralogy of the gabbroic rocks recovered during Leg 153 . This study was conducted on a set of shipboard samples of 55 gabbroic rocks, representative of all lithologies, and primary and metamorphic textural types. The lithologic characterization of the samples is synthesized in Figure 1 and in Table 1. The investigation was performed by means of microstructural analysis, intersection criteria, and blastesisdeformation relationships in the succession of parageneses. In the text, microstructures were described following the indications of Twiss and Moores (1992), and Rutter (1986).

\section{PETROGRAPHIC FEATURES}

Gabbroic rocks show a complex interlayering in modal composition and grain-size changes at the centimeter to meter scale. They are also cut by the impregnation of magmatic veins. Gabbros generally preserve igneous textures and mineral phases (Cannat, Karson, Miller, et al., 1995). Primary igneous textures include random shape fabrics, and foliations and lineations resulting from suprasolidus deformation of the cumulate minerals. Subsolidus crystal-plastic to brittle deformation is generally concentrated in centimeter- to decimeterscale shear zones.

Aphyric to sparsely phyric diabases, ranging in thickness from a decimeter to meter, constitute Unit 2 in Holes 921B and 921C. These rocks have a chilled contact (thickness about $1 \mathrm{~cm}$ ) with the gabbro; based on recovered pieces, the contact is lobate, and locally faulted. Basic intrusive rocks are mainly medium- to coarse-grained gabbros and olivine gabbros with interlayered troctolites; more leucocratic compositions (clinopyroxene + olivine $<30 \%-20 \%$ ) also occur (Table 2). Fe-Ti oxide gabbros are interlayered with the more common gabbros (Table 2). The contacts between gabbros and $\mathrm{Fe}-\mathrm{Ti}$ oxide gabbros are primary and, in most cases, abrupt. Leucocratic magmatic veins are composed of plagioclase, quartz, amphibole, abundant

'Karson, J.A., Cannat, M., Miller, D.J., and Elthon, D. (Eds.), 1997. Proc. ODP, Sci. Results, 153: College Station, TX (Ocean Drilling Program),

2Dipartimento di Scienze della Terra, Università di Genova, Corso Europa 26, I16132 Genova, Italy. gaggero@dister.unige.it zircon and apatite, quartz dioritic veins or dikelets, and trondhjemitic veins (Table 2).

For brevity, we grouped gabbros in two categories: (1) $\mathrm{Mg}-\mathrm{Al}$ gabbros include intrusive rocks enriched in Ca-rich plagioclase and/ or magnesian phases (i.e., troctolites, olivine gabbros, gabbros, and leucocratic gabbros) and (2) Fe-Ti gabbros include intrusive rocks characterized by Fe-Ti oxides $>2 \%$.

\section{Magmatic Textures \\ Random Shape Fabric (Equant Textures)}

In olivine gabbros and troctolites, plagioclase mostly occurs as euhedral to subhedral laths; euhedral to rounded plagioclase as 1- to 2-mm grains commonly occurs within clinopyroxene oikocrysts, more rarely in olivine.

Olivine grains generally are lobate, seldom oikocrystic; in olivine-poor gabbros, olivine can occur as anhedral interstitial grains. In troctolites, olivine also occurs as small euhedral grains, locally included in plagioclase; in the same sample, small euhedral olivine can occur with larger lobate grains. Clinopyroxene generally develops as oikocrysts, which include plagioclase and olivine, or as interstitial grains. Clinopyroxene often exhibits (001) exsolution lamellae at the core and a rim lacking exsolution textures. Large (up to $4.5 \mathrm{~cm}$ ) poikilitic crystals occur in Unit 2 in Hole 922B, Units 3 and 5 in Hole 923A, and Unit 1 in Hole 924C. Olivine is sometimes surrounded by thin, more or less complete, rims of interstitial clinopyroxene. Orthopyroxene rarely occurs as scarce, discrete, elongated grains, mostly in gabbro and $\mathrm{Fe}$-Ti gabbro (Table 3). Ilmenite and Ti-magnetite are common accessory phases. In most cases, ilmenite occurs as exsolution lamellae within Ti-magnetite; moreover, ilmenite can overgrow Ti-magnetite with exsolution lamellae of ilmenite. Both ilmenite and Ti-magnetite occur as monophase inclusions in clinopyroxene or interstitial to plagioclase and olivine. Rare microinclusions of magnetite, acicular Ti oxide, and lamellae of opaque $\mathrm{Fe}-\mathrm{Ti}$ oxides are found in plagioclase (Sample 153-922A-3R-1, 0-6 cm, for instance). Scarce to rare accessory phases are apatite and zircon, which occur as flattened interstitial grains. Spinel and sulfides occur as trace phases in olivine gabbros and troctolites.

Sample 153-921C-2R-1, 9-12 cm, is a diabase that exhibits a porphyritic texture with bimodal plagioclase phenocrysts (5 and $1 \mathrm{~mm}$ ) and rare olivine phenocrysts $(2 \mathrm{~mm})$. The groundmass is ophitic, and 


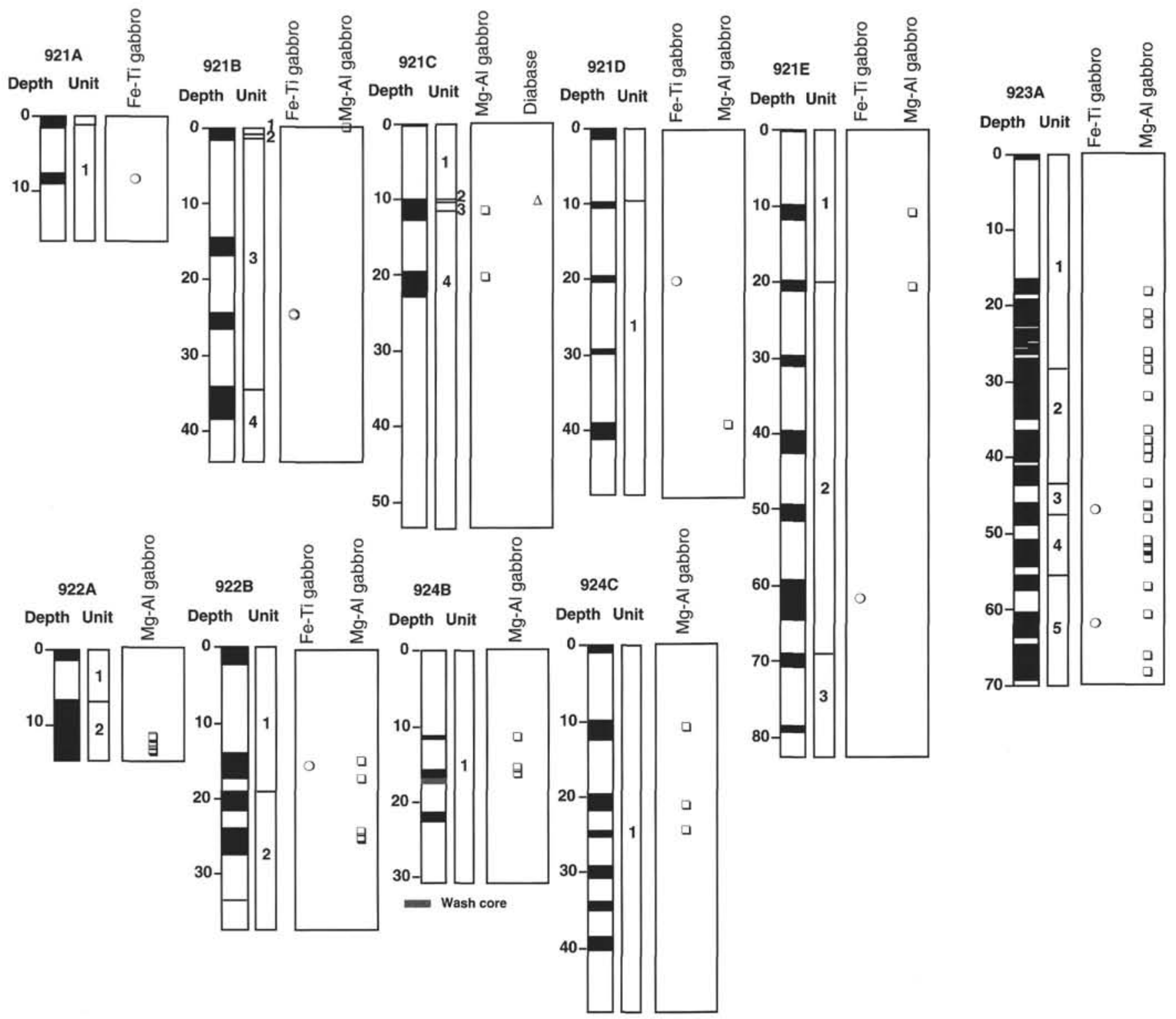

Figure 1. Recovery, lithologic units, rock compositions, and sampling for the gabbroic types considered. Lithologic units, Hole $921 \mathrm{~A}: 1=$ olivine gabbro; Hole 921B: 1 = cataclastic metagabbro, $2=$ aphyric to sparsely phyric diabase, $3=$ lineated gabbro, $4=$ poikilitic olivine gabbro; Hole $921 \mathrm{C}: 1=$ cataclastic metagabbro, 2 = aphyric to sparsely phyric diabase, $3=$ lineated gabbro, 4 = poikilitic olivine gabbro; Hole $921 \mathrm{D}: 1=$ mixed gabbro/olivine gabbro; Hole $921 \mathrm{E}: 1=$ very coarse-grained to pegmatitic gabbro, 2 = heterogeneous poikilitic olivine gabbro, 3 = varitextured gabbro/olivine gabbro; Hole $922 \mathrm{~A}: 1=$ metatroctolite, 2 = troctolite and olivine gabbro; Hole 922B: 1 = troctolite and olivine gabbro, 2 = poikilitic olivine gabbro; Hole 923A: $1=$ variably deformed gabbro and olivine gabbro, 2 = interlayered troctolite and olivine gabbro, 3 = poikilitic olivine gabbro and troctolite, $4=$ varitextured gabbro and olivine gabbro, $5=$ troctolite and poikilitic olivine gabbro; Hole 924B: 1 = lineated gabbro/olivine gabbro; Hole 924C: 1 = poikilitic olivine gabbro/troctolite. Depth is measured in meters below seafloor.

contains interstitial to radiating skeletal clinopyroxene. Ilmenite appears as small interstitial euhedral to skeletal lamellae.

\section{Fabrics Associated With Magmatic Layering}

Foliation and/or lineation defined by preferred-shape elongation of strain-free mineral phases is likely the result of magmatic flow. In some cases, larger crystals showing strain (kink bands, bent twins, and bent cleavages) are overgrown by undeformed rims and lie among smaller, strain-free phases with preferred-shape elongation. Undeformed coronitic rims of clinopyroxene and orthopyroxene are found locally on olivine. Large deformed grains (plagioclase, clinopyroxene, and orthopyroxene) commonly show more magnesian compositions compared to finer, undeformed grains of the same phase.

\section{Subsolidus Deformation Textures}

Subsolidus deformation includes crystal-plastic to brittle deformation. The distribution of deformation intensities through the core has been described in Cannat, Karson, Miller, et al. (1995).

Ductile deformation developed in discrete domains of the core as centimeter- to decimeter-scale shear zones. Ductile shear zones overprint the magmatic foliation at a low $\left(<20^{\circ}\right)$ angle. The transition from undeformed to schistose gabbro may be progressive or abrupt. Low-strain and high-strain fabrics are commonly observed in the same shear zone, and may lie parallel or at a low angle.

Brittle deformation is represented mostly by fractures and veins filled by secondary minerals and less commonly by brittle shear zones (centimeter to decimeter thick) that contain fractured angular clasts in a fine-grained cataclastic matrix. 
Table 1. Samples, lithologic units, detailed petrographic definitions, and textural classification according to Cannat, Karson, Miller, et al. (1995).

\begin{tabular}{|c|c|c|c|}
\hline $\begin{array}{l}\text { Core, sample, } \\
\text { interval }(\mathrm{cm})\end{array}$ & Lithologic unit & Lithotype & $\begin{array}{c}\text { Textural } \\
\text { classification }\end{array}$ \\
\hline $\begin{array}{l}153-921 \mathrm{~A}- \\
2 \mathrm{R}-1,120-124\end{array}$ & 1. Olivine gabbro & Fe-Ti oxide gabbro & $4 a$ \\
\hline $\begin{array}{l}153-921 \mathrm{~B}- \\
1 \mathrm{~W}-1,18-25 \\
3 \mathrm{R}-1,33-36 \\
3 \mathrm{R}-1,46-52\end{array}$ & $\begin{array}{l}\text { 1. Cataclastic metagabbro } \\
\text { 3. Lineated gabbro } \\
\text { 3. Lineated gabbro }\end{array}$ & $\begin{array}{l}\text { Cataclastic metagabbro } \\
\text { Fe-Ti oxide gabbro } \\
\text { Fe-Ti oxide gabbro }\end{array}$ & $\begin{array}{c}5+6 \\
4 b \\
3\end{array}$ \\
\hline $\begin{array}{l}153-921 \mathrm{C}- \\
2 \mathrm{R}-1,9-12 \\
2 \mathrm{R}-2,23-27 \\
3 \mathrm{R}-1,92-98\end{array}$ & $\begin{array}{l}\text { 2. Aphyric to sparsely phyric diabase } \\
\text { 4. Poikilitic olivine gabbro } \\
\text { 4. Poikilitic olivine gabbro }\end{array}$ & $\begin{array}{l}\text { Diabase } \\
\text { Olivine gabbro } \\
\text { Gabbro }\end{array}$ & $3-4 a$ \\
\hline $\begin{array}{l}\text { 153-921D- } \\
3 \mathrm{R}-1,69-75\end{array}$ & 1. Mixed gabbro, olivine gabbro & $\begin{array}{l}\text { Ilmenite-bearing gabbro with plagiogranite } \\
\text { (dioritic) vein } \\
\text { Gabbro }\end{array}$ & $\begin{array}{c}3-4 a \\
3\end{array}$ \\
\hline $\begin{array}{l}5 \mathrm{R}-1,31-35 \\
153-921 \mathrm{E}- \\
2 \mathrm{R}-2,0-3 \\
3 \mathrm{R}-1,99-103 \\
7 \mathrm{R}-2,94-100\end{array}$ & $\begin{array}{l}\text { 1. Very coarse grained to pegmatitic gabbro } \\
\text { 2. Heterogeneous poikilitic olivine gabbro } \\
\text { 3. Heterogeneous poikilitic olivine gabbro }\end{array}$ & $\begin{array}{l}\text { Olivine gabbro } \\
\text { Olivine gabbro } \\
\text { Microgabbro crosscut by quartz diorite }\end{array}$ & $\begin{array}{c}3 \\
1 a+4 a \\
1 a\end{array}$ \\
\hline $\begin{array}{l}153-922 \mathrm{~A}- \\
2 \mathrm{R}-4,110-114 \\
2 \mathrm{R}-4,118-124 \\
2 \mathrm{R}-5,90-95 \\
3 \mathrm{R}-1,0-6 \\
3 \mathrm{R}-1,18-22\end{array}$ & $\begin{array}{l}\text { 2. Melatroctolite } \\
\text { 2. Melatroctolite } \\
\text { 2. Melatroctolite } \\
\text { 2. Melatroctolite } \\
\text { 2. Melatroctolite }\end{array}$ & $\begin{array}{l}\text { Gabbro } \\
\text { Olivine gabbro } \\
\text { Olivine (clinopyroxene, orthopyroxene) gabbro } \\
\text { Olivine gabbro } \\
\text { Gabbro }\end{array}$ & $\begin{array}{c}4 \mathrm{~b} \\
2 \mathrm{a}+4 \mathrm{a} \\
2 \mathrm{a}+4 \mathrm{a} \\
4 \mathrm{~b} \\
4 \mathrm{a}\end{array}$ \\
\hline $\begin{array}{l}153-922 \mathrm{~B}- \\
2 \mathrm{R}-1,104-106 \\
2 \mathrm{R}-2,20-23 \\
2 \mathrm{R}-3,68-78 \\
4 \mathrm{R}-1,48-52 \\
4 \mathrm{R}-1,120-124 \\
4 \mathrm{R}-2,24-30\end{array}$ & $\begin{array}{l}\text { 1. Troctolite and olivine gabbro } \\
\text { 1. Troctolite and olivine gabbro } \\
\text { 1. Troctolite and olivine gabbro } \\
\text { 2. Poikilitic olivine gabbro } \\
\text { 2. Poikilitic olivine gabbro } \\
\text { 2. Poikilitic olivine gabbro }\end{array}$ & $\begin{array}{l}\text { Olivine gabbro } \\
\text { Fe gabbro } \\
\text { Coarse-grained olivine gabbro } \\
\text { Troctolite } \\
\text { Olivine gabbro, troctolite } \\
\text { Olivine gabbro, troctolite }\end{array}$ & $\begin{array}{l}3 \\
4 \mathrm{a} \\
4 \mathrm{a} \\
1 \mathrm{a} \\
1 \mathrm{a} \\
1 \mathrm{a}\end{array}$ \\
\hline $\begin{array}{l}153-923 \mathrm{~A}- \\
2 \mathrm{R}-2,74-82 \\
4 \mathrm{R}-1,44-49 \\
4 \mathrm{R}-1,139-142 \\
6 \mathrm{R}-2,13-18 \\
7 \mathrm{R}-1,87-91 \\
7 \mathrm{R}-2,28-34 \\
9 \mathrm{R}-1,16-19 \\
10 \mathrm{R}-1,18-23 \\
10 \mathrm{R}-2,19-25 \\
10 \mathrm{R}-2,132-138 \\
10 \mathrm{R}-3,113-120 \\
11 \mathrm{R}-2,99-106 \\
12 \mathrm{R}-1,60-65 \\
12 \mathrm{R}-1,74-86 \\
12 \mathrm{R}-1,115-120 \\
12 \mathrm{R}-2,90-94 \\
13 \mathrm{R}-1,39-47 \\
13 \mathrm{R}-1,129-136 \\
\text { 13R-1, 143-145 } \\
\text { 13R-2, 4-10 } \\
13 \mathrm{R}-2,27-36 \\
13 \mathrm{R}-2,127-132 \\
\text { 14R-2, 24-28 } \\
\text { 15R-1, 57-63 } \\
\text { 15R-2, 61-67 } \\
\text { 16R-2, 33-40 } \\
\text { 16R-4, 21-26 }\end{array}$ & $\begin{array}{l}\text { 1. Variably deformed gabbro and olivine gabbro } \\
\text { 1. Variably deformed gabbro and olivine gabbro } \\
\text { 1. Variably deformed gabbro and olivine gabbro } \\
\text { 1. Variably deformed gabbro and olivine gabbro } \\
\text { 1. Variably deformed gabbro and olivine gabbro } \\
\text { 2. Interlayered troctolite and olivine gabbro } \\
\text { 2. Interlayered troctolite and olivine gabbro } \\
\text { 2. Interlayered troctolite and olivine gabbro } \\
\text { 2. Interlayered troctolite and olivine gabbro } \\
\text { 2. Interlayered troctolite and olivine gabbro } \\
\text { 2. Interlayered troctolite and olivine gabbro } \\
\text { 2. Interlayered troctolite and olivine gabbro } \\
\text { 3. Poikilitic olivine gabbro and troctolite } \\
\text { 3. Poikilitic olivine gabbro and troctolite } \\
\text { 3. Poikilitic olivine gabbro and troctolite } \\
\text { 4. Varitextured gabbro and olivine gabbro } \\
\text { 4. Varitextured gabbro and olivine gabbro } \\
\text { 4. Varitextured gabbro and olivine gabbro } \\
\text { 4. Varitextured gabbro and olivine gabbro } \\
\text { 4. Varitextured gabbro and olivine gabbro } \\
\text { 4. Varitextured gabbro and olivine gabbro } \\
\text { 4. Varitextured gabbro and olivine gabbro } \\
\text { 5. Troctolite and poikilitic olivine gabbro } \\
\text { 5. Troctolite and poikilitic olivine gabbro } \\
\text { 5. Troctolite and poikilitic olivine gabbro } \\
\text { 5. Troctolite and poikilitic olivine gabbro } \\
\text { 5. Troctolite and poikilitic olivine gabbro }\end{array}$ & $\begin{array}{l}\text { Granulite } \\
\text { Olivine gabbro } \\
\text { Metagabbro } \\
\text { Olivine gabbro } \\
\text { Olivine gabbro } \\
\text { Medium- to fine-grained olivine gabbro } \\
\text { Olivine (clinopyroxene) gabbro } \\
\text { Gabbro (clinopyroxene } \geq 50 \% \text { ) } \\
\text { Olivine gabbro } \\
\text { Foliated gabbro } \\
\text { Olivine (clinopyroxene) gabbro } \\
\text { Troctolite } \\
\text { Coarse-grained troctolite (orthopyroxene-bearing) } \\
\text { Metagabbro } \\
\text { Olivine gabbro with dioritic vein } \\
\text { Olivine gabbro } \\
\text { Olivine gabbro } \\
\text { Flaser gabbro } \\
\text { Augen olivine gabbro } \\
\text { Augen olivine gabbro } \\
\text { Deformed gabbro } \\
\text { Olivine gabbro } \\
\text { Olivine gabbro } \\
\text { Deformed gabbro } \\
\text { Fe-Ti oxide olivine gabbro } \\
\text { Metagabbro } \\
\text { Deformed olivine gabbro }\end{array}$ & $\begin{array}{c}4 \mathrm{~b} \\
2 \mathrm{~b}+5 \\
4 \mathrm{~b}+5 \\
2 \mathrm{~b}+3 \\
2 \mathrm{~b}+3 \\
1 \mathrm{a} \\
1 \mathrm{a} \\
1 \mathrm{a}+3 \\
2 \mathrm{a}+4 \mathrm{a} \\
3,4 \mathrm{a}, 4 \mathrm{~b}, 5 \\
4 \mathrm{a}, 5,6 \\
3,4 \mathrm{a} \\
1 \mathrm{a} \\
1 \mathrm{a} \\
1 \mathrm{a} \\
4 \mathrm{a} \\
1 \mathrm{a} \\
3,4 \mathrm{~b} \\
3,4 \mathrm{a} \\
3,4 \mathrm{~b} \\
3 / 4 \mathrm{~b} \\
1 \mathrm{a}, 3 \\
3 \\
3 \\
1 \mathrm{a} \\
4 \mathrm{a} \\
3\end{array}$ \\
\hline $\begin{array}{l}153-924 \mathrm{~B}- \\
3 \mathrm{R}-1,4-7 \\
3 \mathrm{R}-1,82-86 \\
4 \mathrm{~W}-1,50-56\end{array}$ & $\begin{array}{l}\text { 1. Lineated gabbro and olivine gabbro } \\
\text { 1. Lineated gabbro and olivine gabbro } \\
\text { 1. Lineated gabbro and olivine gabbro }\end{array}$ & $\begin{array}{l}\text { Olivine gabbro } \\
\text { Olivine gabbro } \\
\text { Olivine gabbro }\end{array}$ & $\begin{array}{c}3 \\
3 \\
1+4 a\end{array}$ \\
\hline $\begin{array}{l}153-924 C- \\
2 R-2,6-13 \\
3 R-2,41-48 \\
4 R-1,37-42\end{array}$ & $\begin{array}{l}\text { 1. Poikilitic olivine gabbro/troctolite } \\
\text { 1. Poikilitic olivine gabbro/troctolite } \\
\text { 1. Poikilitic olivine gabbro/troctolite }\end{array}$ & $\begin{array}{l}\text { Meta-olivine gabbro } \\
\text { Olivine gabbro } \\
\text { Olivine gabbro }\end{array}$ & $\begin{array}{l}1 \mathrm{a} \\
3 \\
3\end{array}$ \\
\hline
\end{tabular}

\section{Ductile Deformation Textures}

Metamorphic minerals in metagabbros affected by ductile deformation include (1) primary relict grains lacking textural evidence of compositional reequilibration, (2) porphyroclasts with compositional zoning caused by partial reequilibration, and (3) neoblastic grains, with polygonal granoblastic textures.

Neoblastic assemblages developed during ductile high-temperature deformation are (1) essentially anhydrous: plagioclase + clinopyroxene + olivine \pm orthopyroxene \pm ilmenite \pm Ti-magnetite, and (2) characterized by the appearance of hornblende as a hydrous phase: plagioclase + clinopyroxene + red hornblende \pm orthopyrox- ene \pm olivine \pm ilmenite + Ti-magnetite. In olivine gabbros and gabbros, anhydrous and hydrous assemblages developed without regard for fabric types, but hornblende-bearing assemblages are more common in pervasively deformed rock domains; hydrous assemblages generally prevail in $\mathrm{Fe}-\mathrm{Ti}$ oxide gabbros. In hornblende-bearing assemblages, orthopyroxene coexists or is replaced by red hornblende.

Brown hornblende occurs rarely as rims on olivine grains. The most common occurrences of red hornblende are (1) as blebs in clinopyroxenes, commonly including small Ti-magnetite grains (Table $3) ;(2)$ as overgrown or filled cracks in clinopyroxene (and orthopyroxene when present) porphyroclasts (Table 3); (3) within neoblastic clinopyroxene ( \pm orthopyroxene) aggregates, commonly as an inter- 
Table 2. Occurrence of leucocratic gabbros and veins downcore.

\begin{tabular}{l} 
Lithotype and modal mineralogy \\
\hline Leucocratic gabbros $(20 \%<\mathrm{Cpx}+\mathrm{Ol}<30 \%$ \\
Pl $60 \%$, oikocrystic $\mathrm{Cpx} 40 \%$ \\
P1 71\% \\
P1 72\% \\
P1 70\% \\
P1 71\% \\
Fe-Ti oxide gabbros
\end{tabular}

Leucocratic magmatic veins ( $\mathrm{Pl}, \mathrm{Qtz}, \mathrm{Am}, \mathrm{Zr}, \mathrm{Ap}$ )

Quartz diorite

Felsic dikelets

Quartz diorite veins or dikelets

Quartz diorite veins or dikelets

Quartz diorite veins or dikelets

Quartz diorite veins or dikelets

Quartz diorite veins or dikelets

Trondhjemite vein

Trondhjemite vein

Trondhjemite vein
Trondhjemite vein

Trondhjemite vein

Trondhjemite vein

Trondhjemite vein

Occurrence

Section 153-921B-4R-4 (Piece 2)

Section 153-922A-3R-1 (Piece 4)

Section 153-923A-11R-1 (Piece 8)

Section 153-923A-12R-1 (Piece 5)

Section 153-923A-16R-3 (Piece 7)

Section 153-921B-3R-1 (Pieces 3-8)

Section 153-921B-2R-1 (Piece 2)

Section 153-921C-2R-1, Unit 3

Section 153-921D-4R-1 (Pieces 4, 6), Unit 1

Section 153-921E-7R-2 (Piece 4),Unit 2

Section 153-921E-8R-1 (Pieces 10, 11)

Section 153-923A-2R-1 (Pieces 1,2)

Section 153-923A-3R-1 (Piece 2)

Section 153-923A-4R-1 (Piece 3,4)

Section 153-921E-8R-1 (Piece 1)

Section 153-921E-8R-1 (Pieces 9-13)

Section 153-922B-1W-1 (Pieces 2B, 5, 9)

Section 153-922B-1W-2 (Pieces 6-8, 10-11)

Section 153-922B-2R-1 (Piece 2A)

Section 153-922B-2R-2 (Piece 1)

Section 153-923A-7R-2 (Pieces 2-8)

Section 153-923A-9R-1 (Piece 1)

Section 153-923A-10R-1 (Piece 5A)

Section 153-923A-12R-2 (Pieces 3, 4, 7, 8A)

Section 153-923A-15R-3 (Piece 3)

Section 153-923A-16R-1 (Piece 1)

Section 153-923A-16R-4 (Pieces 4, 8)

Note: $\mathrm{Cpx}=$ clinopyroxene, $\mathrm{Ol}=$ olivine, $\mathrm{Pl}=$ plagioclase, $\mathrm{Qtz}=$ quartz, $\mathrm{Am}=$ amphibole, $\mathrm{Zr}=\mathrm{zircon}, \mathrm{Ap}=$ apatite.

stitial post-kinematic phase; (4) replacing orthopyroxene; and (5) rimming Ti-magnetite or ilmenite. Red hornblende exhibits no evidence of ductile deformation. Neoblastic ilmenite and Ti-magnetite occur within granoblastic aggregates of pyroxene, but Ti-magnetite is the prevailing phase associated with red hornblende in olivine gabbros and gabbros (Table 3). Zoned red-brown to brown hornblende overgrows red hornblende, generally preceding or associated with brittle deformation (Table 3). In rare cases, red-brown or brown hornblende includes Ti-oxide (rutile?) grains.

\section{Transition from Ductile to Brittle Deformation}

The transition from ductile to brittle deformation is evident in the following:

1. Late cracks, generally showing very low or no displacement $(<1 \mathrm{~mm})$ and opening, develop perpendicular or almost perpendicular to the foliation. Cracks are commonly restricted to porphyroclasts, evidenced in a more ductile behavior of the matrix; elsewhere, cracks cut the metamorphic banding. Dark joints develop in clinopyroxene porphyroclasts. Open $(<<1$ $\mathrm{mm}$ ) cracks, cutting plagioclase, are generally filled by green hornblende and by more sodic plagioclase. Fractures adjacent to ferromagnesian phases are filled by red-brown to browngreen hornblende.

2. Local appearance of fine (maximum size a few $\mathrm{mm}$ ) cataclastic bands parallel or at a low angle to ductile shear zones. Minerals are affected by grain-size reduction and display irregular grain boundaries; the recrystallization extent is generally low. Post-kinematic brown to green hornblende and plagioclase are developed locally.

\section{Brittle Textures}

In the brittle regime, synkinematic to late-kinematic hydrous phases developed extensively as a consequence of fluid mobilization along microveins or cracks. Fractures and veins commonly cut either the fragments or the matrix.
Intersection relationships between fracture sets and mineral assemblages allow us to distinguish the following:

1. Early fractures are filled by low Ca to sodic plagioclase, green hornblende to actinolite, chlorite, and rarely carbonates. Mineral phases of the host rock adjacent to fractures are affected by replacement: plagioclase is altered to more sodic plagioclase, and clinopyroxene is overgrown by green hornblende and/or actinolite \pm chlorite \pm titanite. The mobilization of hydrous fluids led to the pervasive or complete alteration of olivine to hydrous phases. The replacement of olivine is characterized by concentric domains with an outer rim of zoned chlorite (Al content decreases from rim to the core), and a core formed of variable amounts of talc and tremolite.

2. Later fractures cut hornblende-bearing veins. These are characterized by the appearance of actinolite- and prehnite-bearing assemblages (Samples 153-923A-10R-3, 113-120 cm, 16R-2, $33-40 \mathrm{~cm})$. Rare epidote $\left(\mathrm{X}_{\mathrm{Fe} 3+}=0.19-0.22\right)$ occurs in $\mathrm{Mg}-\mathrm{Al}$ gabbros (only in Samples 16R-2, 33-40 cm, and 12R-2, 90-94 $\mathrm{cm})$, and has not been found in Fe-Ti gabbros.

Associated with the development of brown and green hornblende, ilmenite alters to magnetite and titanite. Stilpnomelane, titanite, and chlorite may develop in late prehnite-bearing fractures. In the diabase, olivine is completely chloritized. Diffuse chloritic alteration occurs in the groundmass, with partial albitization of plagioclase. No high-temperature metamorphic effects are documented. The timing of deformation events vs. growth of mineral phases is schematically illustrated in Figure 2.

\section{MINERAL CHEMISTRY}

Quantitative electron microprobe analyses of mineral phases were acquired using a SEM-EDS microprobe installed at the Dipartimento di Scienze della Terra, Università di Genova, equipped with an X-ray dispersive analyzer (EDAX PV 9100). Operating conditions were 15$\mathrm{kV}$ accelerating voltage and $2.20-\mathrm{nA}$ beam current. Natural standards 
Table 3. Occurrences of relevant metamorphic minerals in the studied samples.

\begin{tabular}{ll}
\hline Magmatic orthopyroxene \\
\hline Mg-Al gabbros \\
$924 \mathrm{~B}-3 \mathrm{R}-1,4-7 \mathrm{~cm}$ \\
$922 \mathrm{~A}-2 \mathrm{R}-5,90-95 \mathrm{~cm}$ \\
$923 \mathrm{~A}-10 \mathrm{R}-2,132-138 \mathrm{~cm}$ \\
$923 \mathrm{~A}-13 \mathrm{R}-2,27-36 \mathrm{~cm}$ \\
Fe-Ti gabbros \\
$921 \mathrm{~A}-2 \mathrm{R}-1,120-124 \mathrm{~cm}$ \\
$921 \mathrm{~B}-3 \mathrm{R}-1,33-36 \mathrm{~cm}$ \\
$921 \mathrm{~B}-3 \mathrm{R}-1,92-98 \mathrm{~cm}$ \\
$921 \mathrm{~B}-3 \mathrm{R}-1,46-52 \mathrm{~cm}$ \\
\hline
\end{tabular}

Ductile deformation textures

Red hornblende blebs in clinopyroxene

$\mathrm{Mg}-\mathrm{Al}$ gabbros

921C-3R-1, 92-98 cm

$\mathrm{Fe}-\mathrm{Ti}$ gabbros

921 A $-2 \mathrm{R}-1,120-124 \mathrm{~cm}$

921B-3R-1, 33-36 cm

921B-3R-1, 46-52 cm

921D-5R-1, $31-35 \mathrm{~cm}$

Red hornblende overgrowing clinopyroxene/orthopyroxene porphyroclasts

$$
\begin{aligned}
& \text { Mg-Al gabbros } \\
& 921 \mathrm{C}-2 \mathrm{R}-2,23-27 \mathrm{~cm} \\
& 921 \mathrm{C}-3 \mathrm{R}-1,92-98 \mathrm{~cm} \\
& 921 \mathrm{D}-5 \mathrm{R}-1,31-35 \mathrm{~cm} \\
& 922 \mathrm{~B}-4 \mathrm{R}-2,24-30 \mathrm{~cm} \\
& 923 \mathrm{~A}-15 \mathrm{R}-1,57-63 \mathrm{~cm} \\
& 922 \mathrm{~B}-4 \mathrm{R}-2,24-30 \mathrm{~cm} \\
& 923 \mathrm{~A}-4 \mathrm{R}-1,44-49 \mathrm{~cm} \\
& 924 \mathrm{~B}-3 \mathrm{R}-1,4-7 \mathrm{~cm} \\
& \text { 924C-3R-2, } 41-48 \mathrm{~cm} \\
& \text { Fe-Ti gabbros } \\
& \text { 921A-2R-1, 120-124 cm }
\end{aligned}
$$

Red-brown to brown hornblende overgrowing red hornblende

$$
\mathrm{Mg}-\mathrm{Al} \text { gabbros }
$$

921C-2R-2, 23-27 cm 921E-3R-1, 99-103 cm $922 \mathrm{~A}-2 \mathrm{R}-4,110-114 \mathrm{~cm}$ $922 \mathrm{~A}-2 \mathrm{R}-5,90-95 \mathrm{~cm}$ 922A-3R-1, $18-22 \mathrm{~cm}$ 922B-4R-1, 48-52 cm 923A-13R-2, 127-132 cm $924 \mathrm{C}-4 \mathrm{R}-1,37-42 \mathrm{~cm}$

Fe-Ti gabbros 921A-2R-1, 120-124 cm 921B-3R-1, 33-36 cm 921B-3R-1, 99-103 cm 922 B-2R-2, 20-23 cm $923 \mathrm{~A}-4 \mathrm{R}-1,44-49 \mathrm{~cm}$ 923A-9R-1, 16-19 cm

Oxides: Ti-magnetite associated with red hornblende

$$
\begin{aligned}
& \text { Mg-Al gabbros } \\
& \text { 921C-2R-2, 23-27 cm } \\
& 921 \mathrm{E}-2 \mathrm{R}-2,0-3 \mathrm{~cm} \\
& 922 \mathrm{~A}-2 \mathrm{R}-1,110-114 \mathrm{~cm} \\
& 922 \mathrm{~A}-3 \mathrm{R}-1,18-22 \mathrm{~cm} \\
& 922 \mathrm{~A}-12 \mathrm{R}-1,74-86 \mathrm{~cm} \\
& 923 \mathrm{~A}-13 \mathrm{R}-2,27-36 \mathrm{~cm} \\
& 923 \mathrm{~A}-14 \mathrm{R}-2,24-28 \mathrm{~cm} \\
& \text { Fe-Ti gabbros } \\
& \text { 921A-2R-1, } 120-124 \mathrm{~cm} \\
& \text { 921B-3R-1, 33-36 cm } \\
& \text { 921E-7R-2, } 94-100 \mathrm{~cm}
\end{aligned}
$$

were used. $\mathrm{Na}_{2} \mathrm{O}$ and $\mathrm{MgO}$ contents analyzed in silicates by means of an EDAX microprobe are generally underestimated if the analysis is processed with current automatic methods. To overcome this problem, the background for $\mathrm{Na}(1.040 \mathrm{keV})$ and $\mathrm{Mg}(1.252 \mathrm{keV})$ was manually corrected and considered between 0.9 and $4.2 \mathrm{keV}$. The accuracy of results was checked using the WDS microprobe installed at Università di Modena. Orthopyroxene and clinopyroxene analyses were calculated according to the stoichiometric method of simultaneous normalization to 4.00 cations and 6.00 oxygens, and $\mathrm{Fe}^{3+}=12-$ total cation charge was considered for clinopyroxene. The allocation of cations to sites $\mathrm{T}, \mathrm{M}_{1}$, and $\mathrm{M}_{2}$ was performed according to Morimoto (1988). Analyses were checked according to the rules for "superior quality" of Cameron and Papike (1982). End-members were calculated in the sequence: wollastonite (Wo), enstatite (En), ferrosilite (Fs), pyroxmangite, acmite, jadeite, $\mathrm{CaAl}_{2} \mathrm{SiO}_{6}, \mathrm{CaFeAlSiO}$, $\mathrm{CaCrAlSiO}_{6}, \mathrm{CaTiAl}_{2} \mathrm{O}_{6}$. The nomenclature of Morimoto (1988) and Rock (1990) was adopted. The Ca-amphibole cation sum was normalized to $13-(\mathrm{Ca}+\mathrm{Na}+\mathrm{K})$, as suggested by Laird and Albee (1981); $\mathrm{Fe}^{3+}=46$-total cation charge, and $\mathrm{Fe}^{2+}=\mathrm{Fe}_{\mathrm{tot}}-\mathrm{Fe}^{3+} ; \mathrm{Al}^{\mathrm{VI}}=8$ $-\mathrm{Si}, \mathrm{Al}^{\mathrm{IV}}=\mathrm{Al}_{\text {tot }}-\mathrm{Al}^{\mathrm{VI}}$. The nomenclature of Leake (1978) was adopted. Epidote analyses were recalculated to 8 cations on 12.5 oxygens. Trivalent iron was considered as $\left(3-\mathrm{Al}^{\mathrm{V} 1}-\mathrm{Ti}\right) ; \mathrm{X}\left(\mathrm{Fe}^{3+}\right)=\mathrm{Fe}^{3+} /\left(\mathrm{Fe}^{3+}\right.$ $\left.+\mathrm{Al}^{\mathrm{VI}}\right)$. Plagioclase analyses, on the basis of eight oxygens, were recalculated to total cations $=5$. Ilmenites were recast on the basis of three oxygens; magnetites and Ti-magnetites were recast on the basis of four oxygens.

\section{Clinopyroxene}

In $\mathrm{Mg}$ - $\mathrm{Al}$ gabbros, most magmatic clinopyroxenes are diopside, and ferrosilite enrichment accompanies the change from primitive to evolved bulk-rock compositions $\left(\mathrm{En}_{57-38} \mathrm{Fs}_{19-4} \mathrm{Wo}_{42-22}\right)$. To a minor extent, the ferrosilite component increases from the core to the rim of zoned grains. "Other-than-QUAD" components are very low: jadeite is virtually absent, aegirine ranges between 0 and $0.032 \mathrm{~mol} \%$, pyroxmangite between 0 and $0.006 \mathrm{~mol} \%, \mathrm{CaAl}_{2} \mathrm{SiO}_{6}$ between 0 and $0.043 \mathrm{~mol} \%, \mathrm{CaFeAlSiO}_{6}$ between 0 and $0.047 \mathrm{~mol} \%, \mathrm{CaCrAlSiO}_{6}$ between 0 and $0.033 \mathrm{~mol} \%$, and $\mathrm{CaTiAl}_{2} \mathrm{O}_{6}$ between 0.009 and 0.034 mol\%. In Fe-Ti gabbros, relatively primitive compositions are restricted to the core of zoned grains; the compositional range is $\mathrm{En}_{45-}$ ${ }_{35} \mathrm{FS}_{23-7} \mathrm{Wo}_{44-29}$. "Other-than-QUAD" components are aegirine 0$0.023 \mathrm{~mol} \%$, pyroxmangite $0-0.008 \mathrm{~mol} \%, \mathrm{CaAl}_{2} \mathrm{SiO}_{6} 0-0.026$ $\mathrm{mol} \%, \mathrm{CaFeAlSiO}{ }_{6} 0-0.007 \mathrm{~mol} \%, \mathrm{CaCrAlSiO}_{6} 0-0.035 \mathrm{~mol} \%$, and $\mathrm{CaTiAl}_{2} \mathrm{O}_{6} 0.009-0.028 \mathrm{~mol} \%$. Jadeite is virtually absent.

Apparent exsolution textures are relatively scarce in magmatic pyroxenes, so their composition can be related to crystallization temperatures. According to the isotherms of Lindsley and Anderson (1983), lowest crystallization temperatures are suggested as between $900^{\circ}$ and $800^{\circ} \mathrm{C}$. Early crystallization temperatures (up to $1200^{\circ} \mathrm{C}$ ) are indicated by low $\mathrm{Ca}$ augite compositions measured in the cores of some of the clinopyroxenes. Temperatures about $1100^{\circ} \mathrm{C}$ correspond to the associated orthopyroxene. This suggests that orthopyroxene might be in equilibrium with the early crystallized clinopyroxenes, but disequilibrium occurs between orthopyroxene and late-crystallized clinopyroxene. Coexisting clinopyroxene-orthopyroxene pairs are represented in Figure 3. In neoblastic clinopyroxenes, compositions are restricted to the range $\mathrm{En}_{46-37} \mathrm{Fs}_{16-7} \mathrm{Wo}_{43-33}$ for $\mathrm{Mg}-\mathrm{Al}$ gabbros and $\mathrm{En}_{42-35} \mathrm{Fs}_{20-12} \mathrm{Wo}_{44-37}$ in $\mathrm{Fe}-\mathrm{Ti}$ gabbros (C and $\mathrm{C}^{\prime}$ in Fig. 3). Porphyroclastic clinopyroxenes (B and $\mathrm{B}^{\prime}$ in Fig. 3) display compositions similar to magmatic and neoblastic pyroxenes, implying incomplete reequilibration, in accord with observed textures $\left(\mathrm{En}_{47-}\right.$ ${ }_{38} \mathrm{Fs}_{15-4} \mathrm{Wo}_{42-34}$ in $\mathrm{Mg}-\mathrm{Al}$ gabbros and $\mathrm{En}_{45-35} \mathrm{Fs}_{20-12} \mathrm{Wo}_{44-30}$ in $\mathrm{Fe}-\mathrm{Ti}$ gabbros). Representative compositions are in Tables 4 and 5.

In $\mathrm{Mg}-\mathrm{Al}$ and $\mathrm{Fe}-\mathrm{Ti}$ gabbros, neoblastic clinopyroxenes show $\mathrm{Mg \#}$ and $\mathrm{Al}$ values lower than those of associated igneous rocks. In magmatic clinopyroxene from $\mathrm{Mg}-\mathrm{Al}$ gabbros, $\mathrm{Ti}$ decreases and $\mathrm{Al}$ increases from troctolites to gabbros and from cores to rims (Fig. 4A). Higher $\mathrm{Ti}$ contents are restricted to neoblastic clinopyroxenes from hornblende-free assemblages. In clinopyroxenes coexisting with Ti-rich red hornblende, the Ti content tends to decrease, suggesting that $\mathrm{Ti}$ is preferentially partitioned in the amphibole.

\section{Orthopyroxene}

In magmatic orthopyroxene, the enstatite component decreases from magnesian to $\mathrm{Fe}$-Ti-rich bulk-rock compositions; it varies from $\mathrm{En}_{77}$ to $\mathrm{En}_{58}$ in $\mathrm{Mg}$-Al gabbros and from $\mathrm{En}_{63}$ to $\mathrm{En}_{50}$ in $\mathrm{Fe}$-Ti gabbros 


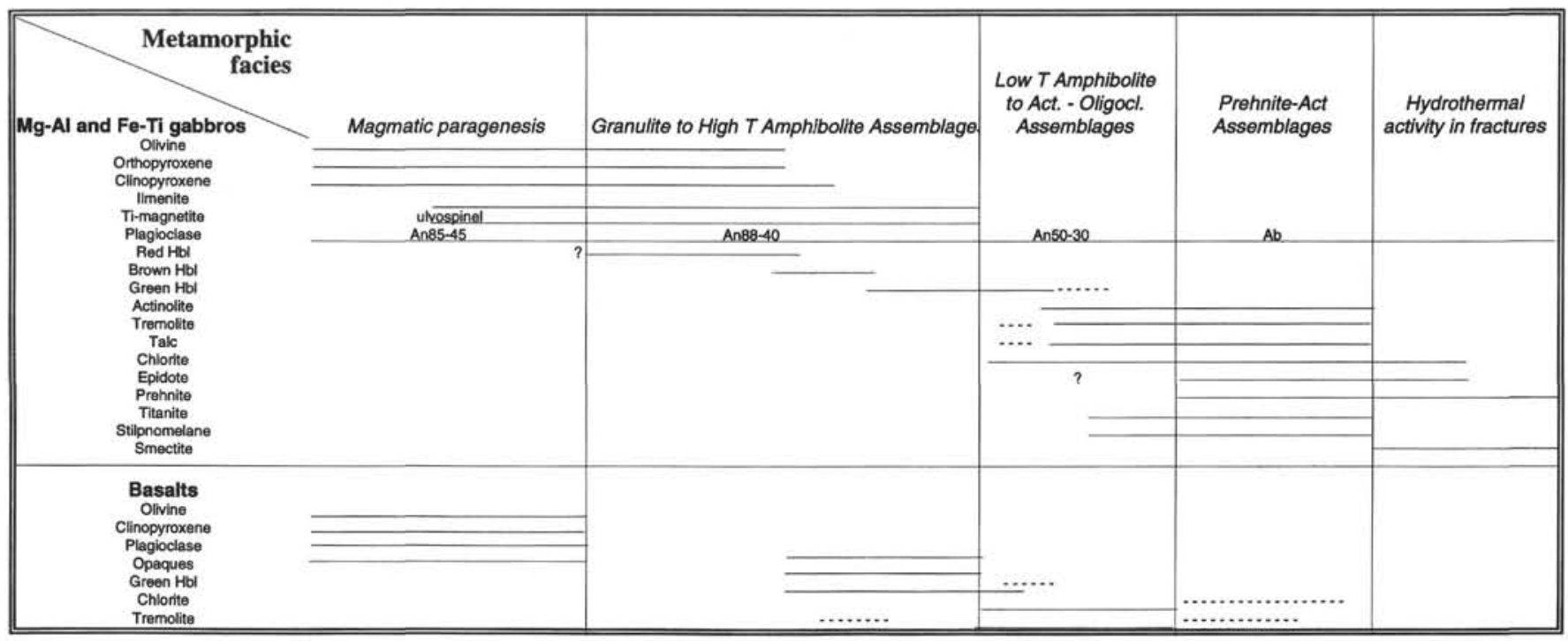

Figure 2. Blastesis/deformation relationships for gabbros and basalt. Full line $=$ stable phase. Dotted line $=$ mineral preserved without evidence of blastesis . $\mathrm{Hbl}=$ hornblende, $\mathrm{T}=$ temperature, Act. $=$ actinolite, Oligocl.$=$ oligoclase.
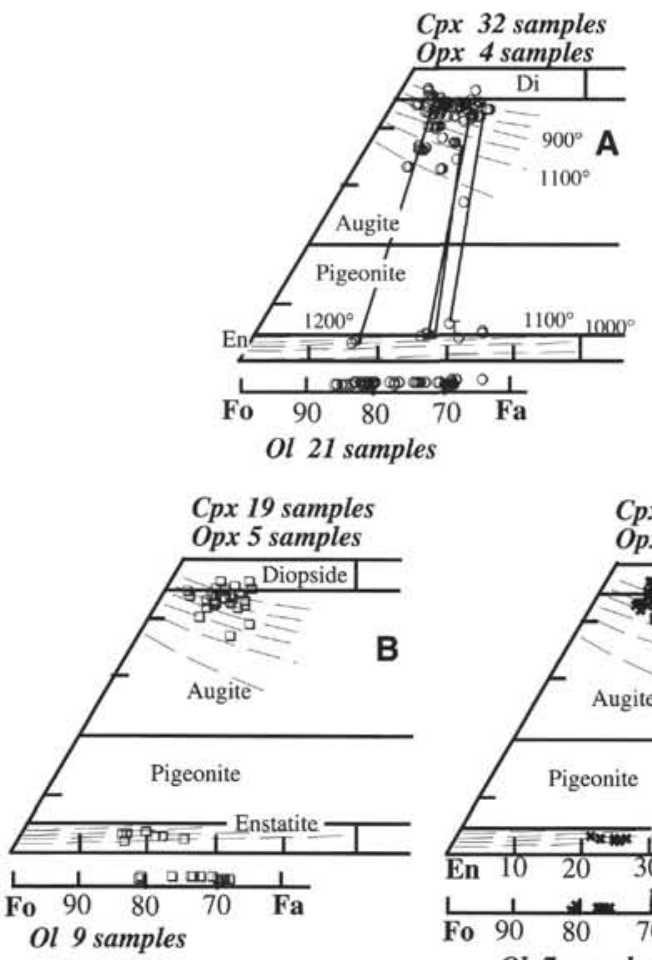

Mg-Al gabbros

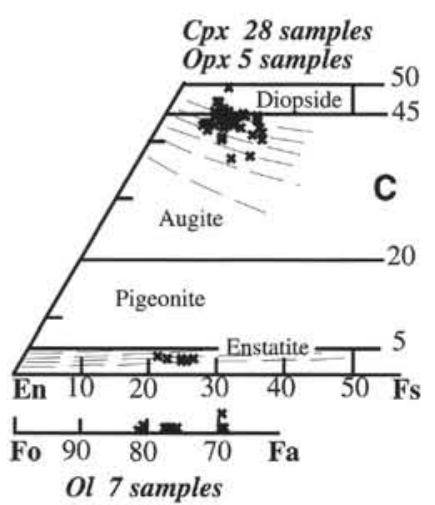

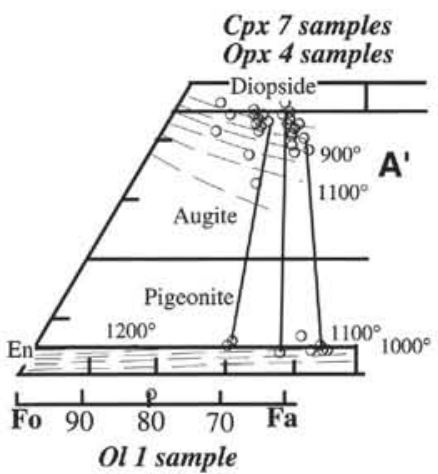

Fe-Ti gabbros
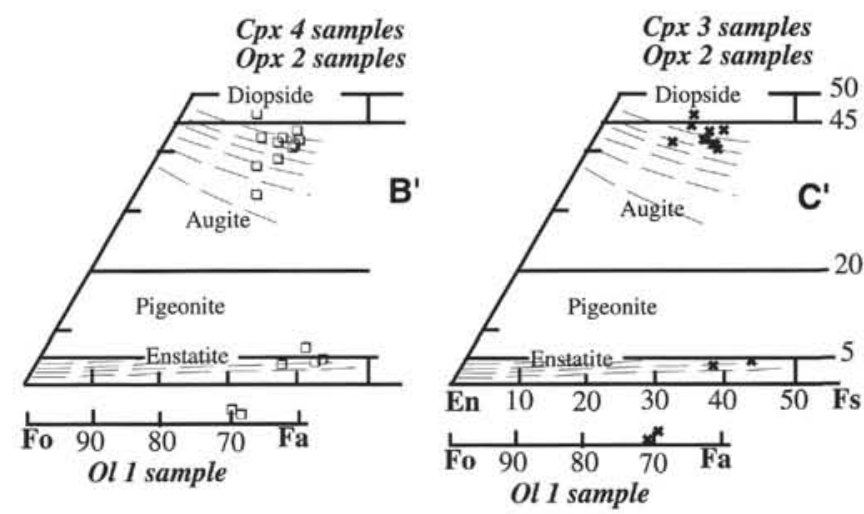

Figure 3. Compositional diagrams for clinopyroxenes (QUAD; Morimoto, 1988) and olivines (forsterite-fayalite-monticellite + tephroite). $\mathbf{A}$ and $\mathbf{A}^{\prime}$. Circles = clinopyroxenes, orthopyroxenes, and olivines lacking evidence of subsolidus reequilibration. Isotherms from Lindsley and Anderson (1983). Tie lines connect orthopyroxenes and clinopyroxenes from the same sample. B and $\mathbf{B}^{\prime}$. Squares $=$ clinopyroxenes, orthopyroxenes, and olivines from porphyroclastic textures. $\mathbf{C}$ and $\mathbf{C}^{\prime}$. Crosses = clinopyroxenes, orthopyroxenes, and olivines in granoblastic textures.

(Fig. 3A). The Wo content is close to $2 \mathrm{~mol} \%$, with rare exceptions of $\mathrm{Wo}_{5}$ (Fig. $3 \mathrm{~A}^{\prime}$ ). However, the higher Wo content may be related to exsolution lamellae smaller than the electron beam. In metamorphic orthopyroxene, the compositional range is restricted between $\mathrm{En}_{71}$ and $\mathrm{En}_{69}$ for $\mathrm{Mg}$ - $\mathrm{Al}$ gabbros and between $\mathrm{En}_{56}$ and $\mathrm{En}_{50}$ for $\mathrm{Fe}$-Ti gabbros; the average Wo content is slightly lower (Figs. 3C, 3C').

\section{Olivine}

Olivines are almost pure forsterite-fayalite (Fo-Fa) solid solutions (Table 6), ranging from $\mathrm{Fo}_{84}$ to $\mathrm{Fo}_{62}$ in $\mathrm{Mg}$ - $\mathrm{Al}$ gabbros, and from $\mathrm{Fo}_{78}$ to $\mathrm{FO}_{77}$ in $\mathrm{Fe}$-Ti gabbros. The lowest $\mathrm{Fo}$ content in $\mathrm{Mg}$ - $\mathrm{Al}$ gabbros is found in the rims of zoned grains. Few data were obtained in $\mathrm{Fe}-\mathrm{Ti}$ 
Table 4. Representative analyses of clinopyroxenes from Mg-Al gabbros. Symbols are the same as in Figure 3.

\begin{tabular}{|c|c|c|c|c|c|c|c|c|c|c|c|}
\hline Hole: & $924 \mathrm{~B}$ & $922 \mathrm{~B}$ & $924 \mathrm{C}$ & $923 \mathrm{~A}$ & $921 \mathrm{E}$ & $922 \mathrm{~B}$ & $923 \mathrm{~A}$ & $924 \mathrm{C}$ & 921D & $923 \mathrm{~A}$ & $924 \mathrm{C}$ \\
\hline Core, section: & $3 R-1$ & $2 \mathrm{R}-3$ & 2R-2 & $10 \mathrm{R}-1$ & 2R-2 & $4 \mathrm{R}-1$ & $7 \mathrm{R}-2$ & $3 R-2$ & $5 \mathrm{R}-1$ & $10 \mathrm{R}-1$ & $3 R-2$ \\
\hline \multirow[t]{2}{*}{ Interval $(\mathrm{cm})$ : } & $4-7$ & $68-73$ & $6-13$ & $18-23$ & $0-3$ & $120-124$ & $28-34$ & $6-13$ & $31-35$ & $18-23$ & $41-48$ \\
\hline & 0 & 0 & 0 & 0 & a & a & a & ב & $\boldsymbol{x}$ & $\boldsymbol{x}$ & $\boldsymbol{x}$ \\
\hline $\begin{array}{l}\mathrm{SiO}_{2}(\mathrm{wt} \%) \\
\mathrm{TiO}_{2} \\
\mathrm{Cr}_{2} \mathrm{O}_{3} \\
\mathrm{Al}_{2} \mathrm{O}_{3} \\
\mathrm{Fe}_{2} \mathrm{O}_{3} \\
\mathrm{FeO} \\
\mathrm{MnO} \\
\mathrm{MgO} \\
\mathrm{CaO} \\
\mathrm{Na}_{2} \mathrm{O} \\
\mathrm{K}_{2} \mathrm{O}\end{array}$ & $\begin{array}{r}53.18 \\
0.50 \\
0.41 \\
2.61 \\
0.00 \\
5.48 \\
0.19 \\
17.64 \\
19.99 \\
0.11 \\
0.12\end{array}$ & $\begin{array}{r}51.95 \\
0.98 \\
0.82 \\
2.78 \\
0.79 \\
3.44 \\
0.10 \\
16.40 \\
23.50 \\
0.00 \\
0.04\end{array}$ & $\begin{array}{r}53.77 \\
0.47 \\
0.40 \\
2.72 \\
0.00 \\
5.13 \\
0.15 \\
17.26 \\
20.85 \\
0.07 \\
0.13\end{array}$ & $\begin{array}{r}51.28 \\
0.81 \\
0.46 \\
2.98 \\
0.92 \\
6.76 \\
0.24 \\
15.03 \\
21.40 \\
0.13 \\
0.08\end{array}$ & $\begin{array}{r}52.77 \\
0.57 \\
0.24 \\
2.41 \\
0.00 \\
8.06 \\
0.15 \\
14.87 \\
21.38 \\
0.00 \\
0.10\end{array}$ & $\begin{array}{r}52.40 \\
0.69 \\
0.39 \\
2.55 \\
2.96 \\
2.70 \\
0.15 \\
16.78 \\
22.22 \\
0.35 \\
0.14\end{array}$ & $\begin{array}{r}51.69 \\
1.18 \\
0.23 \\
3.23 \\
0.00 \\
6.19 \\
0.08 \\
15.25 \\
21.76 \\
0.00 \\
0.04\end{array}$ & $\begin{array}{r}53.61 \\
0.38 \\
0.35 \\
2.46 \\
0.00 \\
5.30 \\
0.13 \\
17.05 \\
21.45 \\
0.00 \\
0.09\end{array}$ & $\begin{array}{r}53.66 \\
0.49 \\
0.00 \\
2.49 \\
0.00 \\
7.04 \\
0.00 \\
15.62 \\
21.59 \\
0.00 \\
0.10\end{array}$ & $\begin{array}{r}52.28 \\
0.71 \\
0.33 \\
2.39 \\
0.44 \\
6.49 \\
0.12 \\
15.44 \\
21.98 \\
0.12 \\
0.10\end{array}$ & $\begin{array}{r}51.51 \\
1.40 \\
0.61 \\
3.69 \\
0.00 \\
5.06 \\
0.15 \\
16.15 \\
21.19 \\
0.15 \\
0.10\end{array}$ \\
\hline Total & 100.23 & 100.80 & 100.95 & 100.09 & 100.55 & 101.34 & 99.65 & 100.82 & 100.99 & 100.40 & 100.01 \\
\hline $\begin{array}{l}\mathrm{Si} \\
\mathrm{Ti} \\
\mathrm{Cr} \\
\mathrm{Al} \\
\mathrm{Fe}^{3+} \\
\mathrm{Fe}^{2+} \\
\mathrm{Mn}^{+} \\
\mathrm{Mg} \\
\mathrm{Ca} \\
\mathrm{Na} \\
\mathrm{K}\end{array}$ & $\begin{array}{l}1.938 \\
0.014 \\
0.012 \\
0.112 \\
0.000 \\
0.167 \\
0.006 \\
0.958 \\
0.780 \\
0.008 \\
0.006\end{array}$ & $\begin{array}{l}1.892 \\
0.027 \\
0.024 \\
0.119 \\
0.022 \\
0.105 \\
0.003 \\
0.890 \\
0.917 \\
0.000 \\
0.002\end{array}$ & $\begin{array}{l}1.948 \\
0.013 \\
0.012 \\
0.116 \\
0.000 \\
0.155 \\
0.005 \\
0.932 \\
0.809 \\
0.005 \\
0.006\end{array}$ & $\begin{array}{l}1.899 \\
0.023 \\
0.014 \\
0.130 \\
0.026 \\
0.209 \\
0.008 \\
0.830 \\
0.849 \\
0.009 \\
0.004\end{array}$ & $\begin{array}{l}1.949 \\
0.016 \\
0.007 \\
0.105 \\
0.000 \\
0.249 \\
0.005 \\
0.819 \\
0.846 \\
0.000 \\
0.005\end{array}$ & $\begin{array}{l}1.896 \\
0.019 \\
0.011 \\
0.109 \\
0.081 \\
0.082 \\
0.005 \\
0.905 \\
0.862 \\
0.025 \\
0.007\end{array}$ & $\begin{array}{l}1.916 \\
0.033 \\
0.007 \\
0.141 \\
0.000 \\
0.192 \\
0.003 \\
0.843 \\
0.864 \\
0.000 \\
0.002\end{array}$ & $\begin{array}{l}1.947 \\
0.010 \\
0.010 \\
0.105 \\
0.000 \\
0.161 \\
0.004 \\
0.923 \\
0.835 \\
0.000 \\
0.004\end{array}$ & $\begin{array}{l}1.962 \\
0.014 \\
0.000 \\
0.107 \\
0.000 \\
0.215 \\
0.000 \\
0.851 \\
0.846 \\
0.000 \\
0.005\end{array}$ & $\begin{array}{l}1.924 \\
0.020 \\
0.010 \\
0.104 \\
0.012 \\
0.200 \\
0.004 \\
0.847 \\
0.867 \\
0.009 \\
0.005\end{array}$ & $\begin{array}{l}1.891 \\
0.039 \\
0.018 \\
0.160 \\
0.000 \\
0.155 \\
0.005 \\
0.884 \\
0.834 \\
0.011 \\
0.005\end{array}$ \\
\hline \multicolumn{12}{|l|}{ End-members } \\
\hline $\begin{array}{l}\text { Wollastonite } \\
\text { Enstatite } \\
\text { Ferrosilite } \\
\text { Pyroxmangite } \\
\text { Acmite } \\
\text { Jadeite } \\
\mathrm{CaAl}_{2} \mathrm{SiO}_{6} \\
\mathrm{CaFeAISiO}_{6} \\
\mathrm{CaCrAISiO}_{6} \\
\mathrm{CaTiAl}_{2} \mathrm{O}_{6}\end{array}$ & $\begin{array}{l}0.37 \\
0.48 \\
0.08 \\
0.00 \\
0.00 \\
0.01 \\
0.02 \\
0.00 \\
0.01 \\
0.01\end{array}$ & $\begin{array}{l}0.42 \\
0.45 \\
0.05 \\
0.00 \\
0.00 \\
0.00 \\
0.01 \\
0.02 \\
0.02 \\
0.03\end{array}$ & $\begin{array}{l}0.39 \\
0.47 \\
0.08 \\
0.00 \\
0.00 \\
0.01 \\
0.02 \\
0.00 \\
0.01 \\
0.01\end{array}$ & $\begin{array}{l}0.39 \\
0.42 \\
0.11 \\
0.00 \\
0.01 \\
0.00 \\
0.03 \\
0.01 \\
0.01 \\
0.02\end{array}$ & $\begin{array}{l}0.41 \\
0.41 \\
0.12 \\
0.00 \\
0.00 \\
0.01 \\
0.01 \\
0.00 \\
0.01 \\
0.02\end{array}$ & $\begin{array}{l}0.39 \\
0.45 \\
0.04 \\
0.00 \\
0.03 \\
0.00 \\
0.01 \\
0.05 \\
0.01 \\
0.02\end{array}$ & $\begin{array}{l}0.41 \\
0.42 \\
0.10 \\
0.00 \\
0.00 \\
0.00 \\
0.01 \\
0.00 \\
0.01 \\
0.03\end{array}$ & $\begin{array}{l}0.40 \\
0.46 \\
0.08 \\
0.00 \\
0.00 \\
0.00 \\
0.02 \\
0.00 \\
0.01 \\
0.01\end{array}$ & $\begin{array}{l}0.41 \\
0.43 \\
0.11 \\
0.00 \\
0.00 \\
0.01 \\
0.01 \\
0.00 \\
0.00 \\
0.01\end{array}$ & $\begin{array}{l}0.41 \\
0.42 \\
0.10 \\
0.00 \\
0.01 \\
0.00 \\
0.03 \\
0.00 \\
0.01 \\
0.02\end{array}$ & $\begin{array}{l}0.38 \\
0.44 \\
0.08 \\
0.00 \\
0.00 \\
0.02 \\
0.01 \\
0.00 \\
0.02 \\
0.04\end{array}$ \\
\hline
\end{tabular}

Table 5. Representative analyses of clinopyroxenes from Fe-Ti gabbros. Symbols are the same as in Figure 3.

\begin{tabular}{|c|c|c|c|c|c|c|c|c|c|}
\hline Hole: & $921 \mathrm{~A}$ & $921 \mathrm{~A}$ & $921 \mathrm{~A}$ & $921 \mathrm{~A}$ & $921 \mathrm{~A}$ & $921 \mathrm{~A}$ & $921 \mathrm{~A}$ & $921 \mathrm{~A}$ & $921 \mathrm{~A}$ \\
\hline Core, section: & $2 \mathrm{R}-1$ & 2R-1 & $2 \mathrm{R}-1$ & $2 \mathrm{R}-1$ & $2 \mathrm{R}-1$ & $2 \mathrm{R}-1$ & $2 R-1$ & $2 \mathrm{R}-1$ & $2 \mathrm{R}-1$ \\
\hline \multirow[t]{2}{*}{ Interval $(\mathrm{cm})$ : } & $120-124$ & $120-124$ & $120-124$ & $120-124$ & $120-124$ & $120-124$ & $120-124$ & $120-124$ & $120-124$ \\
\hline & 0 & 0 & 0 & ב & a & a & $\boldsymbol{x}$ & $x$ & * \\
\hline $\begin{array}{l}\mathrm{SiO}_{2}(\mathrm{wt} \%) \\
\mathrm{TiO}_{2} \\
\mathrm{Cr}_{2} \mathrm{O}_{3} \\
\mathrm{Al}_{2} \mathrm{O}_{3} \\
\mathrm{Fe}_{2} \mathrm{O}_{3} \\
\mathrm{FeO} \\
\mathrm{MnO} \\
\mathrm{MgO} \\
\mathrm{CaO} \\
\mathrm{Na}{ }_{2} \mathrm{O} \\
\mathrm{K}_{2} \mathrm{O}\end{array}$ & $\begin{array}{r}51.63 \\
0.99 \\
0.22 \\
2.87 \\
0.00 \\
8.85 \\
0.24 \\
14.49 \\
20.63 \\
0.11 \\
0.11\end{array}$ & $\begin{array}{r}51.59 \\
0.90 \\
0.19 \\
3.03 \\
0.00 \\
8.71 \\
0.27 \\
14.09 \\
20.69 \\
0.10 \\
0.08\end{array}$ & $\begin{array}{r}51.45 \\
0.98 \\
0.25 \\
2.62 \\
0.06 \\
9.46 \\
0.31 \\
14.52 \\
20.27 \\
0.11 \\
0.09\end{array}$ & $\begin{array}{r}53.65 \\
0.19 \\
0.27 \\
0.90 \\
0.00 \\
8.14 \\
0.31 \\
14.73 \\
22.49 \\
0.00 \\
0.00\end{array}$ & $\begin{array}{r}51.87 \\
0.75 \\
0.22 \\
2.61 \\
0.00 \\
9.43 \\
0.27 \\
14.41 \\
20.25 \\
0.00 \\
0.00\end{array}$ & $\begin{array}{r}52.29 \\
0.78 \\
0.14 \\
2.30 \\
0.00 \\
11.97 \\
0.31 \\
16.48 \\
15.94 \\
0.00 \\
0.00\end{array}$ & $\begin{array}{r}53.37 \\
0.22 \\
0.25 \\
1.02 \\
0.00 \\
8.36 \\
0.26 \\
14.33 \\
22.34 \\
0.00 \\
0.00\end{array}$ & $\begin{array}{r}52.25 \\
0.62 \\
0.00 \\
3.14 \\
0.00 \\
8.87 \\
0.00 \\
13.87 \\
20.74 \\
0.00 \\
0.00\end{array}$ & $\begin{array}{r}51.70 \\
0.79 \\
0.16 \\
2.31 \\
1.00 \\
8.03 \\
0.23 \\
15.53 \\
20.66 \\
0.00 \\
0.04\end{array}$ \\
\hline Total & 100.14 & 99.65 & 100.12 & 100.68 & 99.81 & 100.21 & 100.15 & 99.49 & 100.45 \\
\hline $\begin{array}{l}\mathrm{Si} \\
\mathrm{Ti} \\
\mathrm{Cr} \\
\mathrm{Al} \\
\mathrm{Fe}^{3+} \\
\mathrm{Fe}^{2+} \\
\mathrm{Mn} \\
\mathrm{Mg} \\
\mathrm{Ca} \\
\mathrm{Na} \\
\mathrm{K}\end{array}$ & $\begin{array}{l}1.920 \\
0.028 \\
0.007 \\
0.126 \\
0.000 \\
0.275 \\
0.008 \\
0.803 \\
0.822 \\
0.008 \\
0.005\end{array}$ & $\begin{array}{l}1.929 \\
0.025 \\
0.006 \\
0.134 \\
0.000 \\
0.272 \\
0.009 \\
0.785 \\
0.829 \\
0.007 \\
0.004\end{array}$ & $\begin{array}{l}1.917 \\
0.028 \\
0.007 \\
0.115 \\
0.002 \\
0.295 \\
0.010 \\
0.806 \\
0.809 \\
0.008 \\
0.004\end{array}$ & $\begin{array}{l}1.984 \\
0.005 \\
0.008 \\
0.039 \\
0.000 \\
0.252 \\
0.010 \\
0.812 \\
0.891 \\
0.000 \\
0.000\end{array}$ & $\begin{array}{l}1.940 \\
0.021 \\
0.007 \\
0.115 \\
0.000 \\
0.295 \\
0.009 \\
0.803 \\
0.811 \\
0.000 \\
0.000\end{array}$ & $\begin{array}{l}1.944 \\
0.022 \\
0.004 \\
0.101 \\
0.000 \\
0.372 \\
0.010 \\
0.913 \\
0.635 \\
0.000 \\
0.000\end{array}$ & $\begin{array}{l}1.987 \\
0.006 \\
0.007 \\
0.045 \\
0.000 \\
0.260 \\
0.008 \\
0.795 \\
0.891 \\
0.000 \\
0.000\end{array}$ & $\begin{array}{l}1.958 \\
0.018 \\
0.000 \\
0.139 \\
0.000 \\
0.278 \\
0.000 \\
0.775 \\
0.833 \\
0.000 \\
0.000\end{array}$ & $\begin{array}{l}1.912 \\
0.022 \\
0.005 \\
0.101 \\
0.028 \\
0.248 \\
0.007 \\
0.856 \\
0.819 \\
0.000 \\
0.002\end{array}$ \\
\hline \multicolumn{10}{|l|}{ End-members } \\
\hline $\begin{array}{l}\text { Wollastonite } \\
\text { Enstatite } \\
\text { Ferrosilite } \\
\text { Pyroxmangite } \\
\text { Acmite } \\
\mathrm{Jadeite}_{\mathrm{CaAl}_{2} \mathrm{SiO}_{6}} \\
\mathrm{CaFeAlSiO}_{6} \\
\mathrm{CaCrAlSiO}_{6} \\
\mathrm{CaTiAl}_{2} \mathrm{O}_{6}\end{array}$ & $\begin{array}{l}0.38 \\
0.40 \\
0.14 \\
0.00 \\
0.00 \\
0.01 \\
0.02 \\
0.00 \\
0.01 \\
0.03\end{array}$ & $\begin{array}{l}0.39 \\
0.39 \\
0.14 \\
0.00 \\
0.00 \\
0.01 \\
0.02 \\
0.00 \\
0.01 \\
0.03\end{array}$ & $\begin{array}{l}0.38 \\
0.40 \\
0.15 \\
0.01 \\
0.00 \\
0.01 \\
0.02 \\
0.00 \\
0.01 \\
0.03\end{array}$ & $\begin{array}{l}0.44 \\
0.41 \\
0.13 \\
0.01 \\
0.00 \\
0.00 \\
0.00 \\
0.00 \\
0.01 \\
0.01\end{array}$ & $\begin{array}{l}0.39 \\
0.40 \\
0.15 \\
0.00 \\
0.00 \\
0.00 \\
0.01 \\
0.00 \\
0.01 \\
0.02\end{array}$ & $\begin{array}{l}0.30 \\
0.46 \\
0.19 \\
0.01 \\
0.00 \\
0.00 \\
0.01 \\
0.00 \\
0.00 \\
0.02\end{array}$ & $\begin{array}{l}0.44 \\
0.40 \\
0.13 \\
0.00 \\
0.00 \\
0.00 \\
0.00 \\
0.00 \\
0.00 \\
0.01\end{array}$ & $\begin{array}{l}0.40 \\
0.39 \\
0.14 \\
0.00 \\
0.00 \\
0.00 \\
0.01 \\
0.00 \\
0.00 \\
0.02\end{array}$ & $\begin{array}{l}0.38 \\
0.43 \\
0.12 \\
0.00 \\
0.00 \\
0.00 \\
0.01 \\
0.03 \\
0.01 \\
0.02\end{array}$ \\
\hline
\end{tabular}



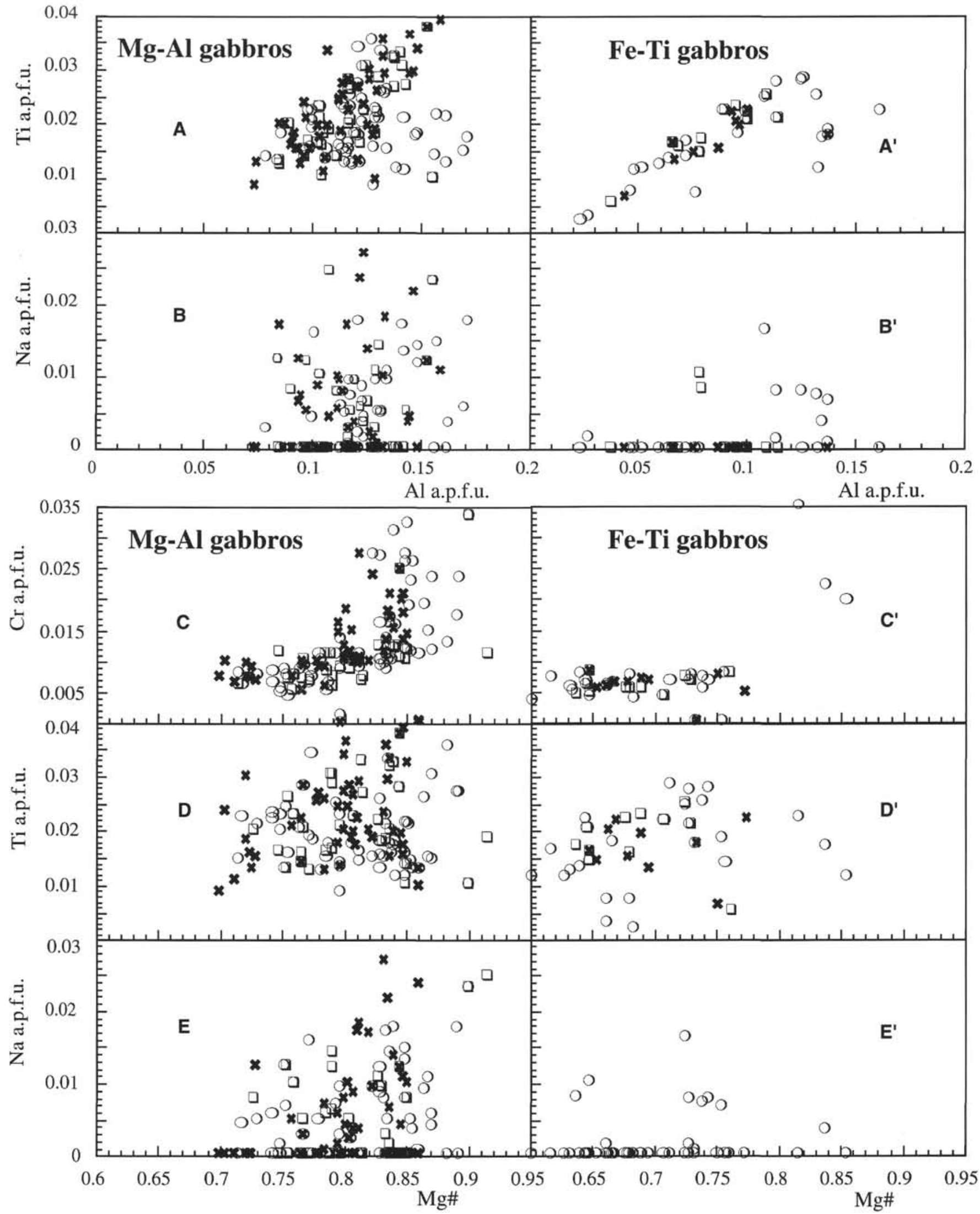

Figure 4. Binary intercationic correlations for clinopyroxenes. Symbols and number of samples are the same as in Figure 3. 
Table 6. Representative analyses of olivines from $\mathrm{Mg}-\mathrm{Al}$ and $\mathrm{Fe}-\mathrm{Ti}$ gabbros. Symbols are the same as in Figure 3.

\begin{tabular}{|c|c|c|c|c|c|c|c|c|}
\hline Hole: & $923 \mathrm{~A}$ & $921 \mathrm{C}$ & $921 \mathrm{C}$ & $921 \mathrm{C}$ & $923 \mathrm{~A}$ & $923 \mathrm{~A}$ & $923 \mathrm{~A}$ & $923 \mathrm{~A}$ \\
\hline Core, section: & $15 \mathrm{R}-2$ & $3 R-1$ & $3 R-1$ & $3 \mathrm{R}-1$ & $10 \mathrm{R}-2$ & $10 \mathrm{R}-2$ & $10 \mathrm{R}-2$ & $11 \mathrm{R}-2$ \\
\hline Interval $(\mathrm{cm})$ : & $61-67$ & $92-98$ & $92-98$ & $92-98$ & $132-138$ & $132-138$ & $132-138$ & $99-106$ \\
\hline & 0 & 0 & 0 & 0 & 口 & a & $\boldsymbol{x}$ & $\boldsymbol{x}$ \\
\hline $\begin{array}{l}\mathrm{SiO}_{2}(\mathrm{wt} \%) \\
\mathrm{TiO}_{2} \\
\mathrm{Cr}_{2} \mathrm{O}_{3} \\
\mathrm{Al}_{2} \mathrm{O}_{3} \\
\mathrm{Fe}_{2} \mathrm{O}_{3} \\
\mathrm{FeO} \\
\mathrm{MnO} \\
\mathrm{MgO} \\
\mathrm{CaO}\end{array}$ & $\begin{array}{r}38.88 \\
0.03 \\
0.06 \\
0.02 \\
0.00 \\
19.38 \\
0.36 \\
41.15 \\
0.13\end{array}$ & $\begin{array}{r}39.25 \\
0.09 \\
0.06 \\
0.00 \\
0.00 \\
19.73 \\
0.34 \\
40.80 \\
0.10\end{array}$ & $\begin{array}{r}38.91 \\
0.10 \\
0.06 \\
0.21 \\
0.00 \\
18.30 \\
0.39 \\
41.51 \\
0.15\end{array}$ & $\begin{array}{r}38.63 \\
0.14 \\
0.11 \\
0.12 \\
0.00 \\
18.55 \\
0.42 \\
41.36 \\
0.17\end{array}$ & $\begin{array}{r}36.00 \\
0.06 \\
0.10 \\
0.05 \\
0.00 \\
27.53 \\
0.52 \\
35.00 \\
0.11\end{array}$ & $\begin{array}{r}36.90 \\
0.08 \\
0.05 \\
0.09 \\
0.00 \\
27.38 \\
0.45 \\
34.92 \\
0.09\end{array}$ & $\begin{array}{r}36.88 \\
0.05 \\
0.03 \\
0.15 \\
0.00 \\
27.42 \\
0.43 \\
34.94 \\
0.96\end{array}$ & $\begin{array}{r}36.42 \\
0.06 \\
0.11 \\
0.02 \\
0.00 \\
28.00 \\
0.47 \\
34.82 \\
0.12\end{array}$ \\
\hline Total & 100.01 & 100.39 & 99.64 & 99.53 & 99.42 & 99.99 & 100.86 & 100.01 \\
\hline $\begin{array}{l}\mathrm{Si} \\
\mathrm{Ti} \\
\mathrm{Cr} \\
\mathrm{Al} \\
\mathrm{Fe}^{3} \\
\mathrm{Fe}^{2} \\
\mathrm{Mn} \\
\mathrm{Mg} \\
\mathrm{Ca}\end{array}$ & $\begin{array}{l}0.997 \\
0.001 \\
0.001 \\
0.001 \\
0.000 \\
0.416 \\
0.008 \\
1.573 \\
0.004\end{array}$ & $\begin{array}{l}1.006 \\
0.002 \\
0.001 \\
0.000 \\
0.000 \\
0.423 \\
0.007 \\
1.558 \\
0.003\end{array}$ & $\begin{array}{l}0.998 \\
0.002 \\
0.001 \\
0.006 \\
0.000 \\
0.393 \\
0.009 \\
1.587 \\
0.004\end{array}$ & $\begin{array}{l}0.993 \\
0.003 \\
0.002 \\
0.004 \\
0.000 \\
0.399 \\
0.009 \\
1.585 \\
0.005\end{array}$ & $\begin{array}{l}0.964 \\
0.001 \\
0.002 \\
0.002 \\
0.000 \\
0.617 \\
0.012 \\
1.397 \\
0.003\end{array}$ & $\begin{array}{l}0.983 \\
0.002 \\
0.001 \\
0.003 \\
0.000 \\
0.610 \\
0.010 \\
1.387 \\
0.003\end{array}$ & $\begin{array}{l}0.975 \\
0.001 \\
0.001 \\
0.005 \\
0.000 \\
0.606 \\
0.010 \\
1.376 \\
0.027\end{array}$ & $\begin{array}{l}0.972 \\
0.001 \\
0.002 \\
0.001 \\
0.000 \\
0.625 \\
0.011 \\
1.385 \\
0.003\end{array}$ \\
\hline
\end{tabular}

gabbros because olivine is rarely preserved by hydrous alteration. Tephroite and monticellite contents are negligible in $\mathrm{Mg}$ - $\mathrm{Al}$ gabbros and increase up to $0.3 \%$ and $0.4 \%$, respectively, in Fe-Ti gabbros (Fig. 3).

\section{Plagioclase}

The anorthite (An) content in magmatic plagioclase depends strongly on the bulk-rock composition and on the textural site (i.e., crystallization timing; Figs. $5 \mathrm{~A}-5 \mathrm{C}$ ). In $\mathrm{Mg}-\mathrm{Al}$ gabbros $\mathrm{An} \geq 80$ corresponds to early crystallized plagioclase in troctolites, whereas late magmatic plagioclases crystallized eutectically with clinopyroxene have an An content of about 51-53. Porphyroclastic and neoblastic plagioclases present An content similar to or slightly lower than the mean value of magmatic plagioclase in the same sample (Figs. 5D, $5 \mathrm{E})$. In textures developed at the ductile-brittle transition, granoblastic plagioclases show compositions in the range of $\mathrm{An}_{50-40}$. Plagioclase filling veins or reequilibrated adjacent to the veins shows maximum $\mathrm{An}_{20}$, with orthoclase (Or) values to 1.9 when coexisting with actinolitic hornblende or actinolite. Nearly pure albite (Ab) coexists with prehnite, epidote, and chlorite. In $\mathrm{Fe}-\mathrm{Ti}$ gabbros magmatic plagioclase is in the range from $\mathrm{An}_{60}$ to $\mathrm{An}_{46}$ (Figs. $5 \mathrm{~A}^{\prime}, 5 \mathrm{~B}^{\prime}$ ), and $\mathrm{An}$ decreases to $46-37$ in plagioclase reequilibrated during the ductile phase (Fig. 5C'). Plagioclase developed along veins and fractures corresponds to $\mathrm{An}_{20-10}$ (Fig. 5D').

\section{Ilmenite and Ti-magnetite}

Ilmenite and Ti-magnetite occur mostly as anhedral grains showing trellis-type textures, and probably represent exsolutions from a high-temperature ulvöspinel. In some cases, Ti-magnetite was corroded and replaced by a silicate matrix intergrown with lamellar ilmenite arranged in the [111] octahedra. Ilmenite also occurs as tiny inclusions in silicates. No appreciable changes in chemistry are observed with recrystallization in ilmenites, whereas neoblastic Timagnetite shows a remarkable increase in $\mathrm{Fe}_{2} \mathrm{O}_{3}$ content (Fig. 6). Magmatic Ti-magnetite has $\mathrm{V}_{2} \mathrm{O}_{3}$ in the range from $1.55 \%$ to $1.45 \%$, lowered to zero with recrystallization. No appreciable $\mathrm{V}_{2} \mathrm{O}_{3}$ is found in ilmenite.

\section{Amphibole}

A correlation exists between the pleochroism of amphiboles (red, red-brown, brown, green, pale green, colorless on $\gamma$ ), their mineral chemistry, and the timing of growth. In both $\mathrm{Mg}-\mathrm{Al}$ and $\mathrm{Fe}-\mathrm{Ti}$ gab- bros, red hornblendes from different textural sites are tschermakite and tschermakitic hornblende, according to Leake's (1978) classification scheme (Fig. 7). The amphibole associated with talc in olivine pseudomorphs and developed during the ductile-brittle transition to brittle phases is tremolite. Representative compositions are reported in Tables 7 and 8 .

A compositional trend from pargasite with minor tschermakite substitution to actinolite is shown by the $100 \mathrm{Na} / \mathrm{Na}+\mathrm{Ca}$ vs. $100 \mathrm{Al} / \mathrm{Al}$ + Si diagram (Figs. 8, 9). The $\mathrm{Al}^{\mathrm{VI}}+\mathrm{Fe}^{3+}+\mathrm{Ti}^{4+}$ vs. $\mathrm{Al}^{\mathrm{IV}}$ shows an early depletion in $\mathrm{Al}^{\mathrm{IV}}$ with decreasing metamorphic grade, and a subsequent decrease in $\mathrm{Al}^{\mathrm{VI}}+\mathrm{Fe}^{3+}+\mathrm{Ti}^{4+}$. A strong correlation between metamorphic grade and $\mathrm{Ti}$ content is evident in Figures 8A and 9A. The partitioning of $\mathrm{Al}^{\mathrm{IV}}$ and $\mathrm{Al}^{\mathrm{VI}}$ in metamorphic amphiboles has been correlated with temperature/pressure conditions by many authors (Fleet and Barnett, 1978; Laird and Albee, 1981; Cortesogno and Lucchetti, 1984; Cortesogno et al., 1994). In Figure 10, analyzed amphiboles exhibit $\mathrm{Al}^{\mathrm{IV}} / \mathrm{Al}^{\mathrm{VI}}$ higher than in pargasitic substitution.

\section{SUMMARY}

The textural features of gabbroic rocks from Sites 921 to 924 show that deformation began under suprasolidus conditions and continued into lower temperature hydrous conditions.

A moderate degree of metamorphic recrystallization can be detected even in rock domains not showing evident deformation, far from foliated portions. These recrystallization processes are characterized by compositional zoning localized at the edge of grains, neoblast growth at the edges of large crystals, grain boundary migration, and subgrain bulging. In $\mathrm{Mg}$ - $\mathrm{Al}$ gabbros and $\mathrm{Fe}-\mathrm{Ti}$ gabbros, associated with these deformation features, red hornblende commonly appears (i) as blebs parallel to exsolution lamellae in clinopyroxenes, commonly replacing the exsolved orthopyroxene, and (ii) as interstitial phase in subgrains of clinopyroxene, commonly associated with Fe-Ti oxides. A slight increase of hornblende abundance is accompanied by increasing deformation. Only in well-developed porphyroclastic and/or granoblastic textures, red hornblende grows as rims on clinopyroxene, and more rarely, on olivine. Red hornblende was not observed in structures lacking indicators of subsolidus recrystallization. Furthermore, red hornblende was never found to be affected by later ductile deformation. In other cases, the red hornblende blebs occurring in clinopyroxene in gabbros have been considered as a product of late magmatic crystallization (Hébert et al., 1983; Bideau et al. 1991). 


\section{Mg-Al gabbros}

\section{Fe-Ti gabbros}

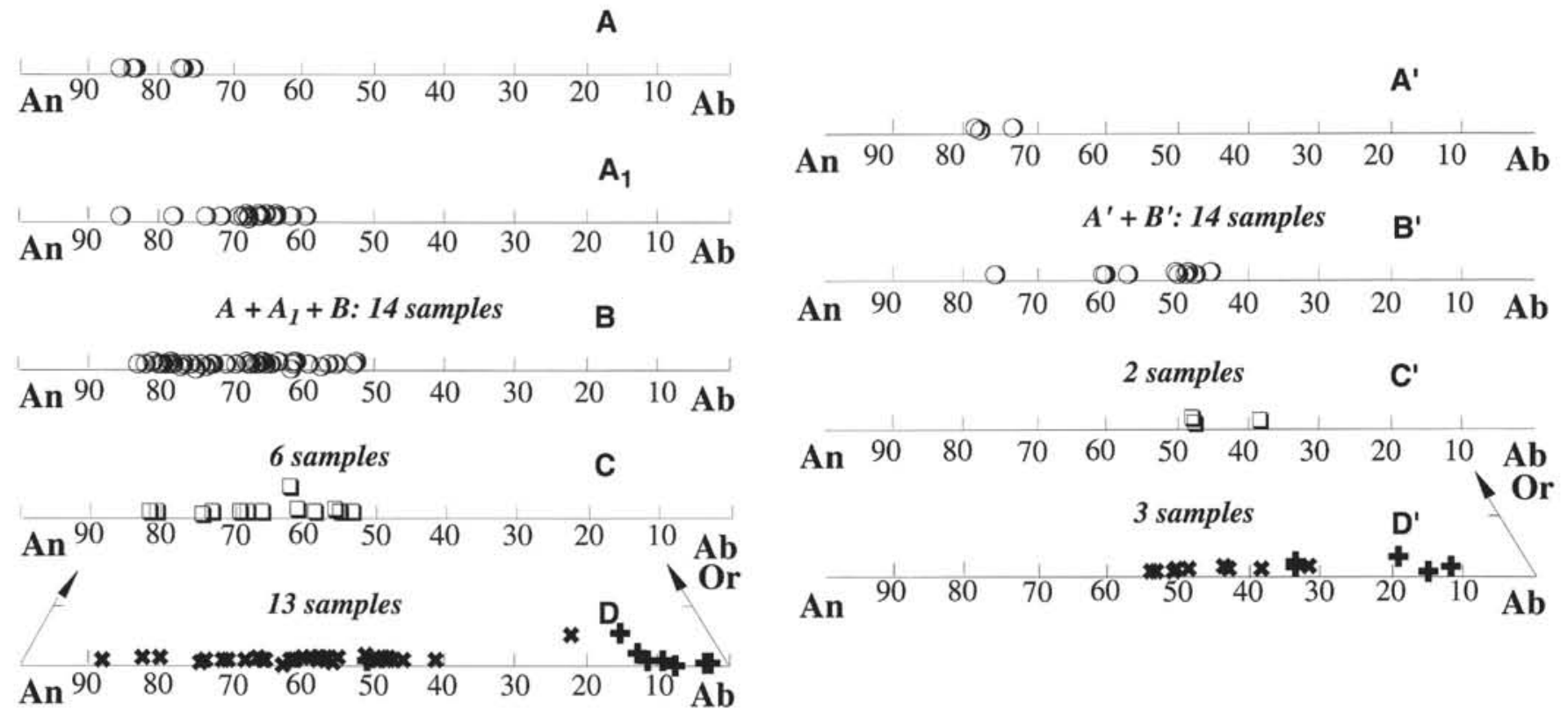

Figure 5. Compositional diagram An-Ab-Or for plagioclases. A. Circles = plagioclase grains completely to partially included in oikocrystic to "amoeboid" olivine. $\mathbf{A}_{\mathbf{1}}$ and $\mathbf{A}^{\prime}$. Circles = grains included in oikocrystic clinopyroxene. $\mathbf{B}$ and $\mathbf{B}^{\prime}$. Circles = lath-shaped to subhedral, more or less zoned grains. Lower An contents correspond to rims of zoned grains. $\mathbf{C}$ and $\mathbf{C}^{\prime}$. Squares = porphyroclastic plagioclase in "augen" metagabbros. $\mathbf{D}$ and $\mathbf{D}$ '. Oblique crosses $=$ granoblastic plagioclase in banded metagabbros. $\mathbf{D}$ and $\mathbf{D}^{\prime}$. Vertical crosses: plagioclase newly formed in fracture zones,

Figure 6. Compositional diagram $\left(\mathrm{FeO}-\mathrm{Fe}_{2} \mathrm{O}_{3}-\mathrm{TiO}_{2}\right)$ for ilmenites and $\mathrm{Ti}$-magnetites from $\mathrm{Mg}-\mathrm{Al}$ gabbros and $\mathrm{Fe}$ Ti gabbros. $\mathbf{A}$ and $\mathbf{A}^{\prime}$. Open circles = primary ilmenite and Ti-magnetite. $\mathbf{B}$ and $\mathbf{B}^{\prime}$. Open squares = partially recrystallized Fe-Ti oxide in porphyroclastic textures. $\mathbf{C}$ and $\mathbf{B}^{\prime}$. Crosses $=$ granoblastic ilmenites and $\mathrm{Ti}$-magnetite in shear bands.

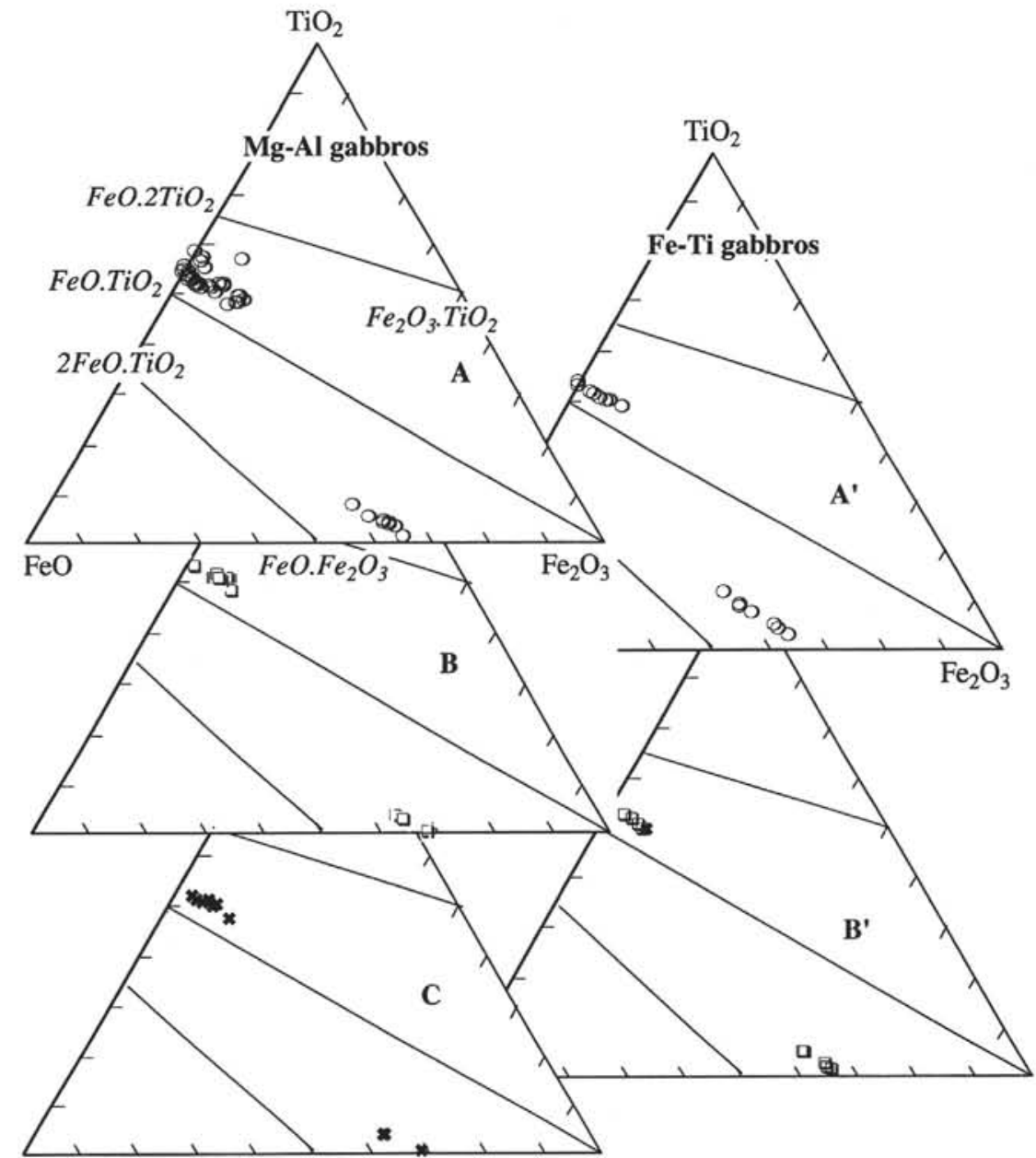




\section{Mg-Al gabbros}

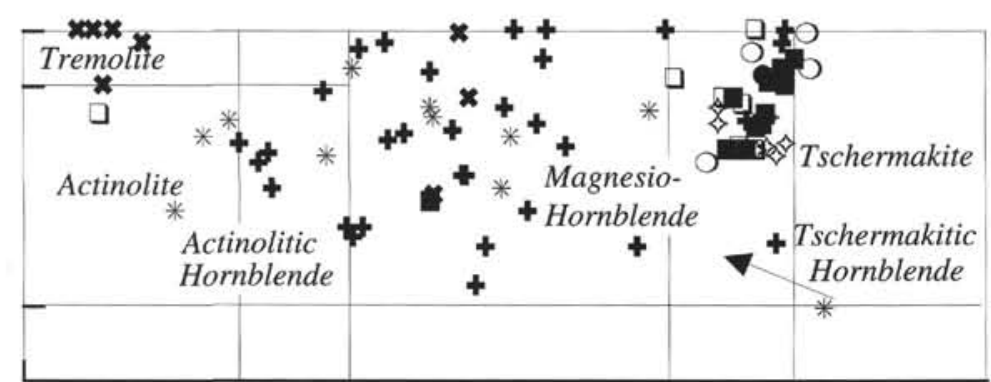

Fe-Ti gabbros

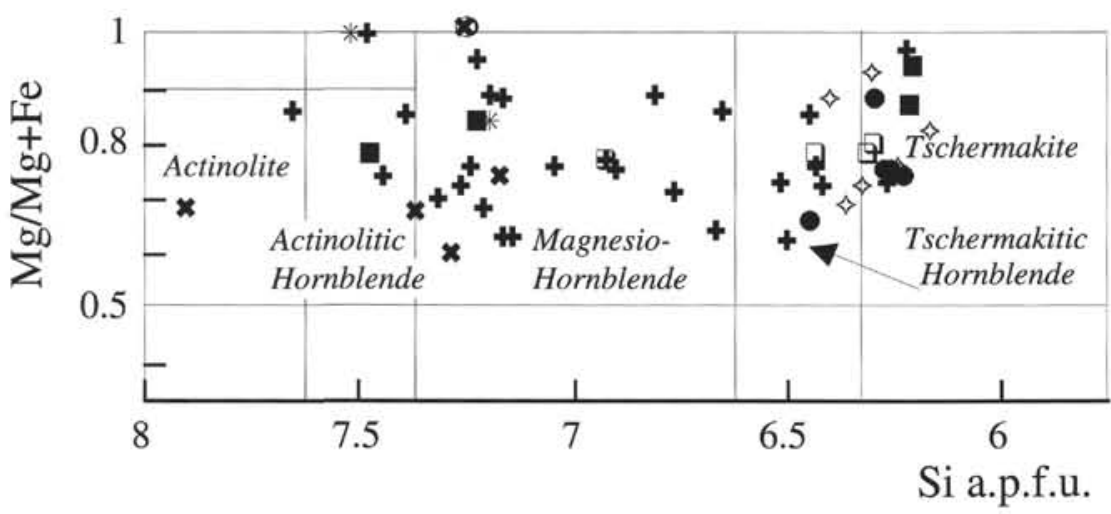

Figure 7. Classification diagram for amphiboles (Leake, 1978). From "augen" textures: solid circle $=$ red hornblende bleb in clinopyroxenes; open square $=$ red hornblende rimming clinopyroxene; open circle $=$ red hornblende rimming olivine; solid square $=$ red hornblende rimming Fe-Ti oxide. From granoblastic textures: diamond $=$ red hornblende in granoblastic textures + clinopyroxene \pm orthopyroxene \pm plagioclase. Ductile-brittle transition: vertical cross = later brown and browngreen hornblende rimming red hornblende and filling extensional cracks in grains; oblique cross = light- green amphibole rimming or replacing olivine. From brittle textures: asterisk $=$ green amphibole + plagioclase filling fractures. The abbreviation a.p.f.u. $=$ atoms per formula unit.

\section{ACKNOWLEDGMENTS}

This work was carried out with the CNR-Italy contribution A.I. 94.00868. The authors wish to thank L. Negretti for help in mineral data acquisition.

\section{REFERENCES}

Bideau, D., Hébert, R., Hékinian, R., and Cannat, M., 1991. Metamorphism of deep-seated rocks from the Garrett ultrafast transform (East Pacific Rise near $13^{\circ} 25^{\prime}$ S). J. Geophys. Res., 96:10079-10099.

Cameron, M., and Papike, J.J., 1982. Crystal chemistry of silicate pyroxene. Mineral. Soc. Am., Rev. Mineral., 7.

Cannat, M., Karson, J.A., Miller, D.J., et al., 1995. Proc. ODP, Init. Repts., 153: College Station, TX (Ocean Drilling Program).

Cortesogno, L., Gaggero, L., and Molli, G., 1994. Ocean floor tectono-metamorphic evolution in the Piedmont-Ligurian Jurassic basin: a review. Mem. Soc. Geol. Ital., 48:151-163

Cortesogno, L., and Lucchetti, G., 1984. Ocean floor metamorphism of metagabbros and striped amphibolites (T. Murlo, Southern Tuscany, Italy). Neues Jahrb. Mineral. Abh., 148:276-300.

Fleet, M.E., and Barnett, R.L., 1978. $\mathrm{Al}^{\mathrm{IV}} / \mathrm{Al}^{\mathrm{VI}}$ partitioning in calciferous amphiboles from the Frood mine, Sudbury, Ontario. Can. Mineral., $16: 527-532$.
Hébert, R., Bideau, D., and Hékinian, R., 1983. Ultramafic and mafic rocks from the Garret transform fault near $13^{\circ} 30^{\prime} \mathrm{S}$ on the East Pacific Rise: igneous petrology. Earth Planet. Sci. Lett., 65:107-125.

Laird, J., and Albee, A.L., 1981. Pressure, temperature, and time indicators in mafic schist: their application to reconstructing the polymetamorphic history of Vermont. Am. J. Sci., 281:97-126.

Leake, B.E., 1978. Nomenclature of amphiboles. Can. Mineral., 16:501520.

Lindsley, D.H., and Andersen, D.J., 1983. A two-pyroxene thermometer. $J$. Geophys. Res., 88 (Suppl.):A887-A906.

Morimoto, N., 1988. Nomenclature of pyroxenes. Schweiz. Mineral. Petrogr. Mitt., 68:95-111.

Rock, N.M.S., 1990. The International Mineralogical Association (IMA CNMMN) pyroxene nomenclature scheme: computerization and its consequences. Mineral. Petrol., 43:99-119.

Rutter, E.H., 1986. On the nomenclature and mode of failure transitions in rocks. Tectonophysics, 122:381-387.

Twiss, R.J., and Moores, E.M., 1992. Structural Geology: New York (Freeman).

Date of initial receipt: 3 August 1995

Date of acceptance: 26 January 1996

Ms 153SR-035 
Table 7. Representative analyses of calcic amphiboles from $\mathrm{Mg}$ - $\mathrm{Al}$ gabbros.

\begin{tabular}{|c|c|c|c|c|c|c|c|c|c|c|c|c|c|c|c|c|c|c|c|c|c|}
\hline Hole: & $921 \mathrm{C}$ & $923 \mathrm{~A}$ & $923 \mathrm{~A}$ & $923 \mathrm{~A}$ & $922 \mathrm{~B}$ & $924 \mathrm{C}$ & $921 \mathrm{C}$ & $921 \mathrm{C}$ & $921 \mathrm{C}$ & $922 \mathrm{~A}$ & $923 \mathrm{~A}$ & $922 \mathrm{~A}$ & $922 \mathrm{~A}$ & $924 \mathrm{C}$ & $924 \mathrm{C}$ & $922 \mathrm{~A}$ & $923 \mathrm{~A}$ & $923 \mathrm{~A}$ & $924 \mathrm{C}$ & $924 \mathrm{C}$ & $922 \mathrm{~A}$ \\
\hline Core, section: & $3 \mathrm{R}-1$ & $4 \mathrm{R}-1$ & $4 \mathrm{R}-1$ & $12 \mathrm{R}-1$ & $4 \mathrm{R}-2$ & $4 \mathrm{R}-1$ & $2 \mathrm{R}-2$ & $2 \mathrm{R}-2$ & $2 \mathrm{R}-2$ & $3 R-1$ & $13 \mathrm{R}-2$ & $3 R-1$ & $3 R-1$ & $3 R-2$ & $3 \mathrm{R}-2$ & $2 \mathrm{R}-5$ & $14 \mathrm{R}-2$ & $14 \mathrm{R}-2$ & $4 \mathrm{R}-1$ & $4 \mathrm{R}-1$ & $3 R-1$ \\
\hline Interval $(\mathrm{cm})$ : & 92-98 & $44-49$ & $44-49$ & $115-120$ & $24-30$ & $37-42$ & $23-27$ & $23-27$ & $23-27$ & $18-22$ & $127-132$ & $18-22$ & $18-22$ & $41-48$ & $41-48$ & 90-95 & $24-28$ & $24-28$ & $37-42$ & $37-42$ & $0-6$ \\
\hline & - & ם & ם & O & 0 & $\diamond$ & $\diamond$ & $\diamond$ & $\diamond$ & $\diamond$ & $\diamond$ & + & + & $\boldsymbol{x}$ & $\boldsymbol{x}$ & $\mathbf{x}$ & * & * & * & * & * \\
\hline $\mathrm{SiO}_{2}(\mathrm{wt} \%)$ & 42.42 & 44.15 & 44.03 & 44.74 & 44.19 & 48.50 & 47.58 & 47.70 & 47.58 & 44.00 & 52.02 & 49.85 & 51.52 & 56.50 & 49.37 & 47.98 & 46.25 & 51.60 & 53.25 & 47.77 & 41.21 \\
\hline $\mathrm{TiO}_{2}$ & 2.55 & 3.27 & 3.49 & 3.23 & 0.58 & 1.74 & 1.50 & 0.95 & 1.50 & 1.77 & 0.44 & 0.21 & 0.21 & 0.02 & 0.11 & 0.30 & 0.31 & 0.20 & 0.18 & 0.24 & 0.20 \\
\hline $\mathrm{Cr}_{2} \mathrm{O}_{3}$ & 1.23 & 0.20 & 0.20 & 0.15 & 0.27 & 0.21 & 0.13 & 0.14 & 0.13 & 0.30 & 1.14 & 0.00 & 0.03 & 0.11 & 0.08 & 0.07 & 0.21 & 0.20 & 0.16 & 0.12 & 0.06 \\
\hline $\mathrm{Al}_{2} \mathrm{O}_{3}$ & 11.26 & 11.24 & 11.70 & 11.83 & 11.94 & 8.01 & 8.25 & 7.36 & 8.25 & 12.33 & 3.87 & 4.45 & 3.18 & 1.09 & 8.61 & 6.49 & 11.36 & 5.58 & 2.73 & 8.79 & 15.72 \\
\hline $\mathrm{Fe}_{2} \mathrm{O}_{3}$ & 4.69 & 7.84 & 6.63 & 7.31 & 6.25 & 7.96 & 8.54 & 6.13 & 8.54 & 9.71 & 4.05 & 11.87 & 12.65 & 4.22 & 3.85 & 10.71 & 8.41 & 7.55 & 4.33 & 6.63 & 6.40 \\
\hline $\mathrm{FeO}$ & 2.59 & 5.47 & 4.93 & 1.30 & 7.54 & 1.92 & 5.35 & 8.67 & 5.35 & 0.76 & 8.06 & 9.31 & 9.02 & 4.06 & 4.55 & 8.90 & 4.61 & 2.38 & 12.17 & 9.30 & 13.60 \\
\hline $\mathrm{MnO}$ & 0.00 & 0.18 & 0.09 & 0.10 & 0.20 & 0.12 & 0.21 & 0.13 & 0.21 & 0.24 & 0.28 & 0.12 & 0.30 & 0.15 & 0.20 & 0.27 & 0.13 & 0.33 & 0.32 & 0.42 & 0.18 \\
\hline $\mathrm{MgO}$ & 16.04 & 14.14 & 14.73 & 16.53 & 13.33 & 17.48 & 14.49 & 13.37 & 14.49 & 16.02 & 15.70 & 12.02 & 11.99 & 19.86 & 17.39 & 11.47 & 14.68 & 17.80 & 13.60 & 12.70 & 7.60 \\
\hline $\mathrm{CaO}$ & 11.48 & 11.06 & 11.39 & 11.75 & 12.30 & 11.58 & 10.85 & 11.70 & 10.85 & 11.40 & 12.24 & 10.77 & 10.37 & 12.71 & 12.54 & 11.35 & 12.27 & 11.90 & 12.07 & 12.03 & 11.53 \\
\hline $\mathrm{Na}_{2} \mathrm{O}$ & 2.35 & 2.29 & 2.15 & 1.56 & 1.84 & 1.52 & 1.62 & 0.87 & 1.62 & 2.11 & 0.30 & 0.55 & 0.23 & 0.00 & 1.65 & 0.00 & 1.25 & 0.65 & 0.06 & 0.97 & 1.91 \\
\hline $\mathrm{K}_{2} \mathrm{O}$ & 0.05 & 0.34 & 0.26 & 0.22 & 0.18 & 0.28 & 0.21 & 0.07 & 0.21 & 0.37 & 0.27 & 0.08 & 0.10 & 0.07 & 0.12 & 0.02 & 0.23 & 0.27 & 0.15 & 0.13 & 0.20 \\
\hline $\mathrm{H}_{2}^{2} \mathrm{O}$ & 2.03 & 2.12 & 2.12 & 2.13 & 2.07 & 2.15 & 2.10 & 2.05 & 2.10 & 2.12 & 2.10 & 2.08 & 2.09 & 2.17 & 2.13 & 2.05 & 2.13 & 2.14 & 2.09 & 2.09 & 2.02 \\
\hline Total & 96.69 & 102.29 & 101.72 & 100.85 & 100.69 & 101.47 & 100.84 & 99.14 & 100.84 & 101.14 & 100.47 & 101.31 & 101.69 & 100.97 & 100.60 & 99.61 & 101.83 & 100.60 & 101.11 & 101.19 & 100.65 \\
\hline $\mathrm{Si}$ & 6.254 & 6.258 & 6.239 & 6.285 & 6.386 & 6.768 & 6.781 & 6.960 & 6.781 & 6.209 & 7.412 & 7.202 & 7.390 & 7.798 & 6.942 & 7.029 & 6.521 & 7.216 & 7.632 & 6.865 & 6.115 \\
\hline $\mathrm{Ti}$ & & & & & & & & & & & & 0 & 0 & & & & 0.0 & 0.6 & & & 0.023 \\
\hline $\mathrm{Cr}$ & 3 & 0.022 & 0.022 & 0 & 0. & 0. & 5 & 0.0 & 0.015 & 0.034 & 0.1 & 0 & 0. & 0 & 0. & 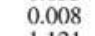 & 0.0 & 0.022 & 8 & 4 & 0.007 \\
\hline $\mathrm{Al}$ & 1.956 & 1.878 & 1.954 & 1.959 & 2. & 1.317 & 1.386 & 1.266 & 1.3 & 2.051 & 0.650 & 0.758 & 0.538 & 0. & 1. & 1.1 & 1.8 & 0.920 & 0. & & 2.749 \\
\hline $\mathrm{Fe}$ & 0.520 & 0.836 & 0.707 & 0.773 & 0.679 & 0.836 & 0.916 & 0.673 & 0.916 & 1.032 & 0.434 & 1.291 & 1.365 & 0. & 0.407 & 1.181 & 0.892 & 0.795 & 67 & 0.717 & 0.715 \\
\hline $\mathrm{Fe}^{2}$ & 0.319 & 0.648 & 0.585 & 0.1 & 0.911 & 0.224 & 0.6 & 1.058 & 0.638 & 0.090 & 0.960 & 1.124 & 1.082 & 0.469 & 0.535 & 1.091 & 0.543 & 0.278 & 1.458 & 1.118 & 1.687 \\
\hline $\mathrm{Mn}$ & & 0.0 & 0.0 & & & 0.0 & 0.0 & & 0.0 & 0.0 & 0.0 & & $0 .($ & & 0.0 & & 0.0 & & & & 0.023 \\
\hline $\mathrm{Mg}$ & 3.5 & 2.9 & 3.1 & & 2.8 & & 3.0 & & 3.0 & & & & & & & & 3.0 & 3.7 & 2.905 & & 1.682 \\
\hline C & 1.813 & 1.680 & 1.729 & 1.7 & 1.905 & 1.731 & 1.6 & 1.829 & 1.6 & 1.724 & 1.8 & 1.667 & 1.594 & 1.880 & 1.8 & 1.782 & 1.854 & 1.783 & 1.854 & 1.852 & 1.833 \\
\hline $\mathrm{Na}$ & 0.672 & 0.629 & 0.591 & 0.4 & 0.516 & 0.411 & 0.4 & 0.246 & 0.448 & 0.577 & 0.0 & 0.154 & 0.064 & 0.000 & 0.450 & 0.000 & 0.342 & 0.176 & 0.017 & 0.270 & 0.551 \\
\hline $\mathrm{K}$ & 0.009 & 0.062 & 0.047 & 0.040 & 0.033 & 0.050 & 0.038 & 0.013 & 0.038 & 0.067 & 0.049 & 0.015 & 0.018 & 0.012 & 0.022 & 0.004 & 0.041 & 0.048 & 0.027 & 0.024 & 0.038 \\
\hline $\mathrm{OH}$ & 2.000 & 2.000 & 2.000 & 2.000 & 2.000 & 2.000 & 2.000 & 2.000 & 2.000 & 2.000 & 2.000 & 2.000 & 2.000 & 2.000 & 2.000 & 2.000 & 2.000 & 2.000 & 2.000 & 2.000 & 2.000 \\
\hline
\end{tabular}

Notes: Cations calculated on the basis of 23 oxygens and 13 cations $+\mathrm{K}+\mathrm{Na}+\mathrm{Ca}$. Symbols are the same as in Figure 7. 
Table 8. Representative analyses of calcic amphiboles from Fe-Ti gabbros.

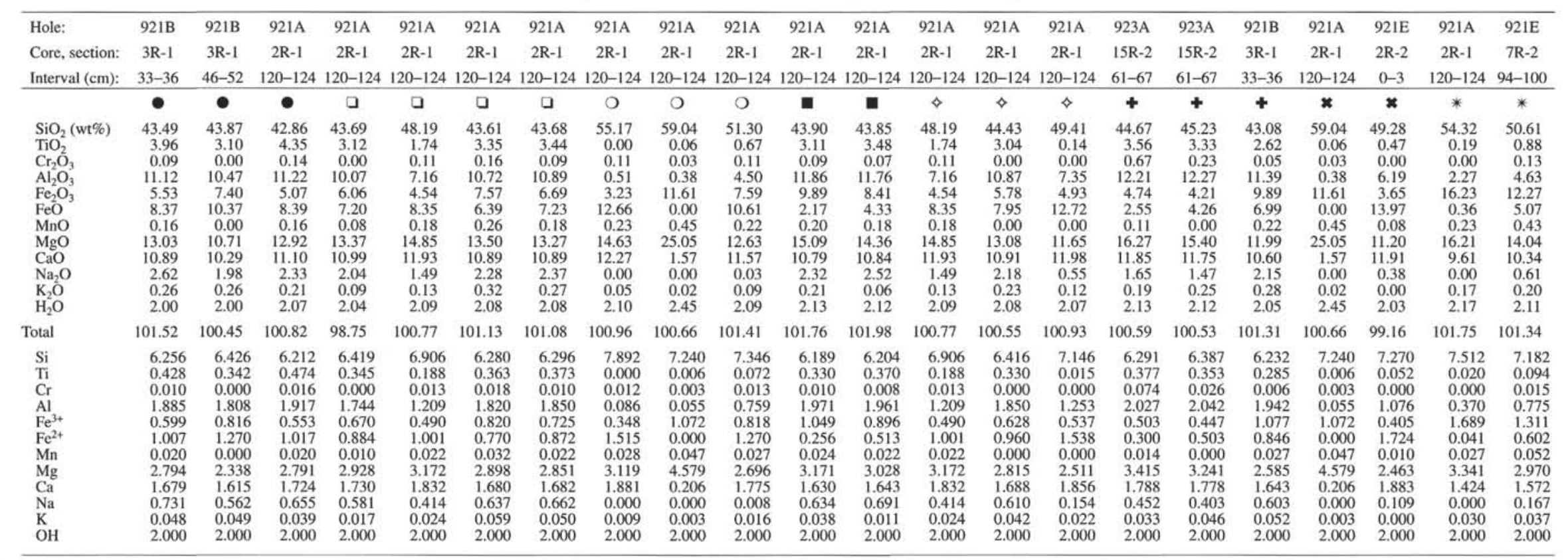

Notes: Cations calculated on the basis of 23 oxygens and 13 cations $+\mathrm{K}+\mathrm{Na}+\mathrm{Ca}$. Symbols are the same as in Figure 7. 

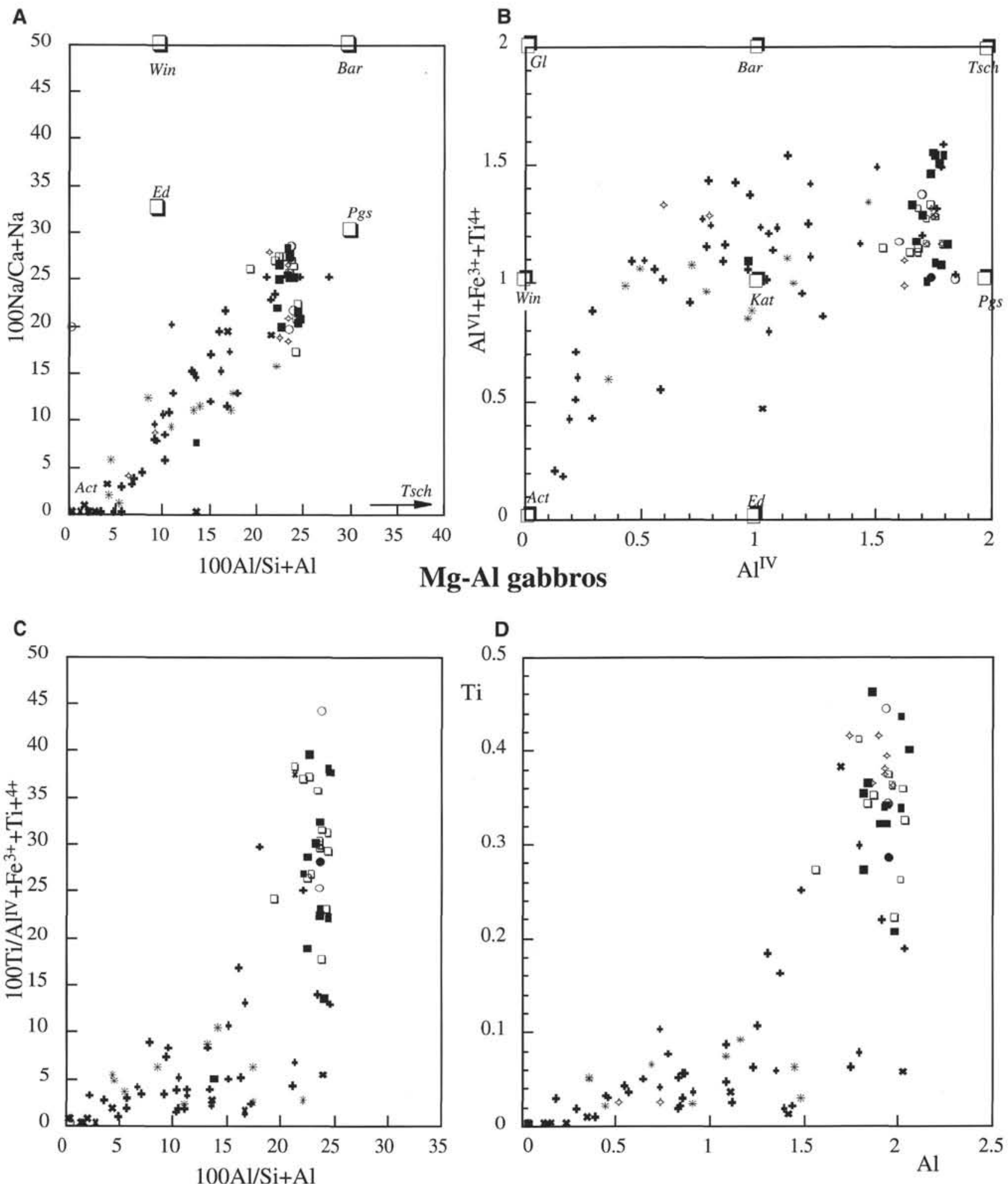

Figure 8. Binary intercationic correlations for amphiboles in Mg-Al gabbros. A, B, D from Laird and Albee (1981). Symbols are the same as in Figure 7. 
A

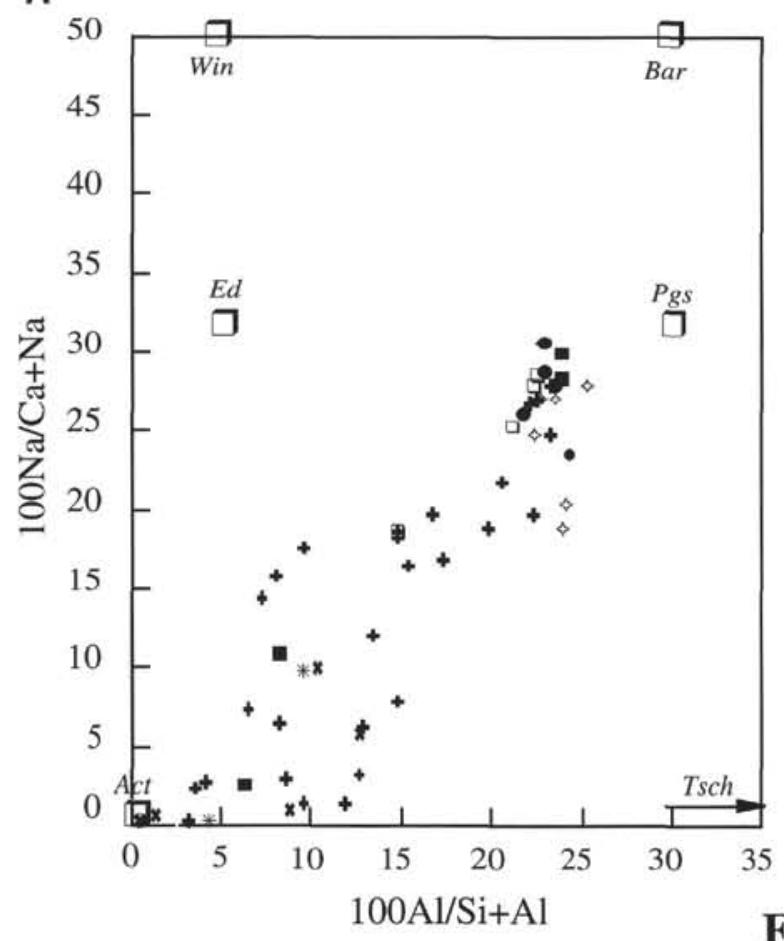

\section{Fe-Ti gabbros}

C

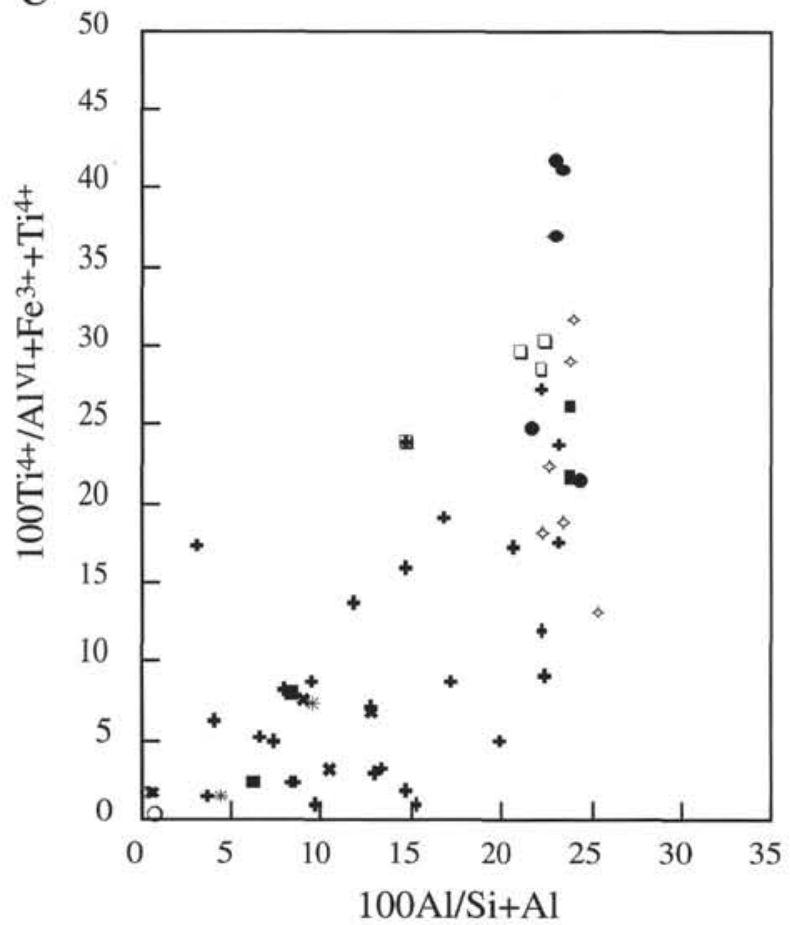

B
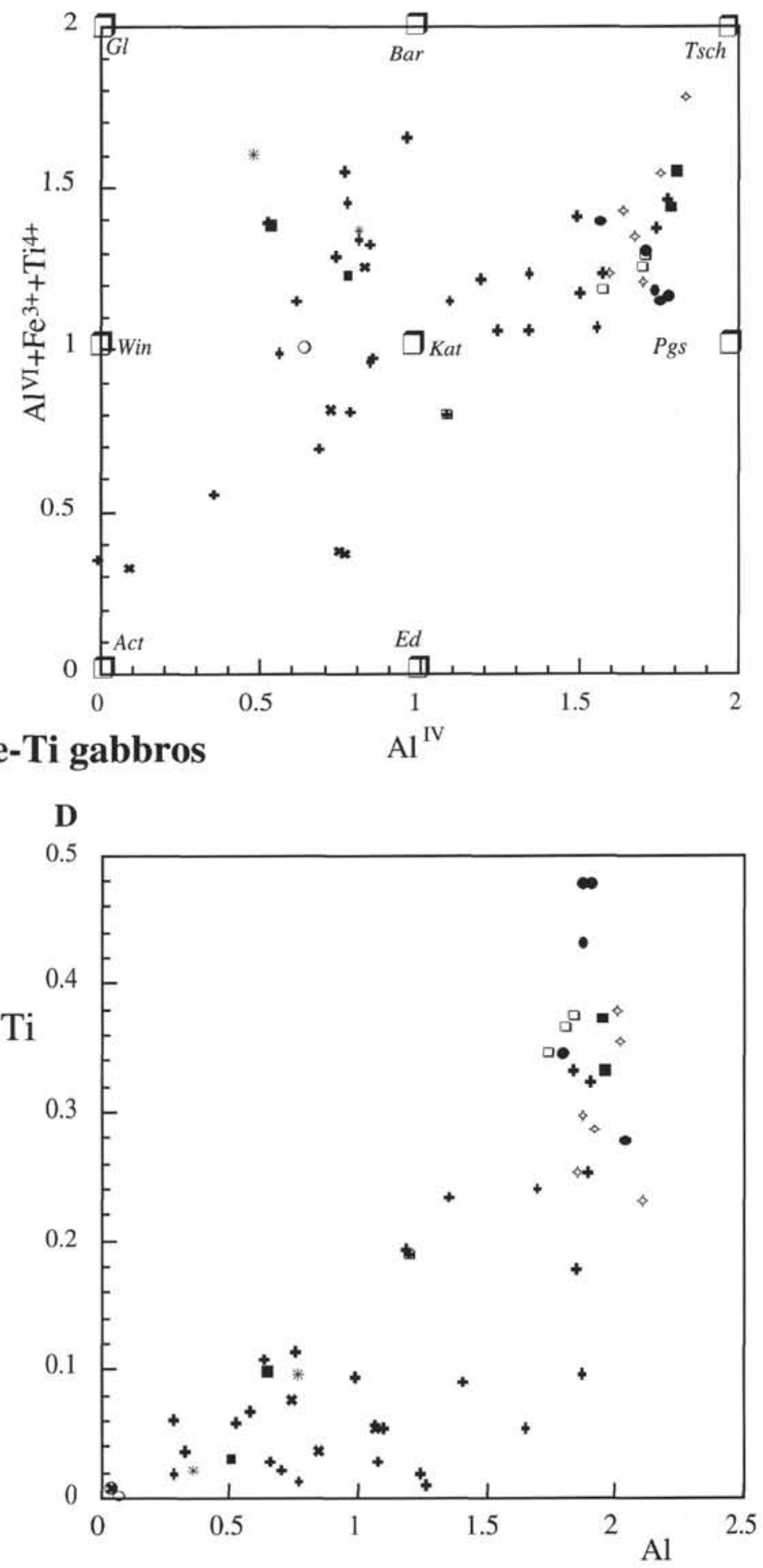

Figure 9. Binary intercationic correlations for amphiboles in Fe-Ti gabbros. A, B, D from Laird and Albee (1981). Symbols are the same as in Figure 7. 

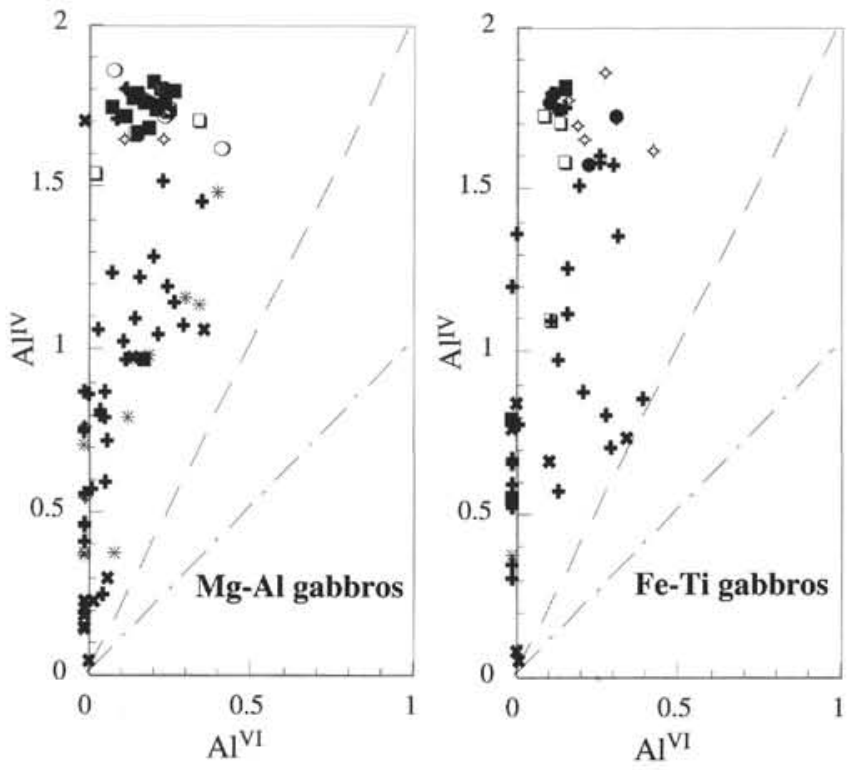

Figure 10. $\mathrm{Al}^{\mathrm{IV}}: \mathrm{Al}^{\mathrm{VI}}$ ratio for $\mathrm{Mg}-\mathrm{Al}$ gabbros and $\mathrm{Fe}-\mathrm{Ti}$ gabbros. Dashed line $=$ pargasitic substitution; dashed-dotted line $=$ tschermakitic substitution. Symbols are the same as in Figure 7. 